Luciana Miwa Nita

\title{
Estudo histoquímico e ultra-estrutural da distribuição das fibras da matriz extracelular na prega vocal humana fetal no período perinatal
}

Tese apresentada à Faculdade de Medicina da Universidade de São Paulo para obtenção do título de Doutor em Ciências

Área de concentração: Otorrinolaringologia Orientador: Prof. Dr. Domingos Hiroshi Tsuji

São Paulo

2008 


\title{
Dados Internacionais de Catalogação na Publicação (CIP)
}

\author{
Preparada pela Biblioteca da
}

Faculdade de Medicina da Universidade de São Paulo

Creprodução autorizada pelo autor

\section{Nita, Luciana Miwa}

Estudo histoquímico e ultra-estrutural da distribuição das fibras da matriz extracelular na prega vocal humana fetal no período perinatal / Luciana Miwa Nita. -- São Paulo, 2008.

Tese(doutorado)--Faculdade de Medicina da Universidade de São Paulo. Departamento de Oftalmologia e Otorrinolaringologia.

Área de concentração: Otorrinolaringologia.

Orientador: Domingos Hiroshi Tsuji.

Descritores: 1.Cordas vocais 2.Feto 3.Matriz extracelular 4.Ligamentos 5.Colágeno 6.Tecido elástico 7.Laringe 8.Tecido conjuntivo 
Aos meus pais, Yoshifiro e Ana, pelo amor, pela dedicação, pelo exemplo, a minha gratidão eterna.

Ao meu esposo, Tsuneyoshi, pelo apoio e pela compreensão, com todo o meu amor. 


\section{AGRADECIMENTOS}

Agradeço

Ao Prof. Dr. Domingos Tsuji, orientador desta tese, meu mestre, com muita admiração, em quem gostaria de me espelhar pelo seu exemplo como profissional e pela amizade enriquecedora.

À Profa. Dra. Elia Caldini, chefe do Laboratório de Biologia celular, por toda a sua contribuição e amor à pesquisa, por seus admiráveis caráter e dedicação, um exemplo de profissional e pessoa.

Ao Prof. Dr. Ricardo Ferreira Bento, Professor Titular da Disciplina de Clínica Otorrinolaringológica da Faculdade de Medicina da Universidade de São Paulo pela constante e incansável luta em prol de nossa Clínica, por todas as oportunidades que ofereceu desde o nosso ingresso na especialidade.

Ao Prof. Dr. Aroldo Miniti, ex-Professor Titular da Disciplina de Clínica Otorrinolaringológica da Faculdade de Medicina da Universidade de São Paulo, por todo o seu empenho nestes anos dedicados à nossa Clínica.

Ao Prof. Dr. Ossamu Butugan, por todos os conselhos e ensinamentos transmitidos com muita sabedoria durante estes anos de nossa formação.

Aos Prof. Dr. Ivan Miziara, Dr. Henry Koishi, Dr. Luiz Antonio Figueiredo, Dr. Michel Cahali, Prof. Dr. Richard Voegels, pelas observações pertinentes e valiosas por ocasião do nosso exame de qualificação. 
Ao Prof. Dr. Luiz Ubirajara Sennes, Coordenador do Programa de Pósgraduação em Otorrinolaringologia da Faculdade de Medicina da USP, pelo incentivo à pesquisa e dedicação aos pós-graduandos.

Ao Dr. Rui Imamura, por todos os seus inestimáveis ensinamentos, conselhos e contribuições, especialmente na área de Laringologia.

Ao Prof. Dr. Hiroyuki Fukuda, Professor e Chefe do Tokyo Voice Center, por toda a sua dedicação e gentileza com que me acolheu durante o estágio no exterior.

Ao Prof. Dr. Hélio Élkis, Docente do Departamento de Psiquiatria da FMUSP, pelo incentivo à pesquisa nos tempos da faculdade.

Ao Prof. Dr. Paulo Saldiva, Professor Titular do Departamento de Patologia da FMUSP, pelo seu incentivo à realização desta pesquisa e por seus valiosos conselhos.

À Dra. Claudia Battlehner, do Departamento de Patologia da FMUSP, por todos os seus ensinamentos durante o desenvolvimento do estudo.

A todos os funcionários do Laboratório de Biologia Celular (LIM 59) do Hospital das Clínicas da Faculdade de Medicina da USP, pelo carinho com que sempre me acolheram e, em especial, à Íris Amorim e ao Dr. Marcelo Ferreira Alves, por sua dedicação na confecção do material estudado e ao seu auxílio direto no desenvolvimento deste estudo.

Ao Prof. Dr. Carlos Augusto G. Pasqualucci, diretor do SVOC-USP, que permitiu o acesso às laringes utilizadas, e a todos seus funcionários, em especial ao Sr. Nilton que tornou possível a obtenção do material de estudo. 
Aos Drs. Adriana Hachiya, Clarissa Komatsu, Fabio Lorenzetti, Francisco Amorim, Leila Freire, Maura Neves, Patricia Santoro, Renata Marcondes, Ronaldo Frizzarini e Saramira Bohadana, meus queridos amigos e companheiros de profissão, com quem sei poder contar sempre.

Aos amigos do Grupo de Laringologia do Departamento de Otorrinolaringologia do HCFMUSP, Drs. Christian Wiikmann, Daniel Chung, Erich Melo, Flavio Sakae, João Ximenes, Natasha Braga, Rafael Cahali, Raquel Tavares, Rogério Buhler, pelo companheirismo nestes anos de Pós-graduação e tantas sugestões a este trabalho.

À Dra. Silvia Pinho, Fonoaudióloga da área de voz, por seus enriquecedores conhecimentos e colaboração profissional.

Aos meus amigos, Drs. Elder Goto, Fabrizio Romano, Gilberto Takahashi, Ítalo Medeiros, Lucinda Simoceli, Marcio Nakanishi, Marcus Lessa, Milton Takeuti, pelos valiosos exemplos e conselhos.

Aos meus amigos, Drs. Adriana Yoshimura, Alexandre Mitsuuchi, Bráulio de Oliveira, Fabiana Hashimoto, Fabio Imoto, Felipe Vanderlei, Fernanda Pereira, Humberto Kishi, Jacqueline Hirahara, Luci Kimura, Marcos Ozaki, Otávio Ninomiya, Paolo Biseli e Vivian Lanzarini, pelo apoio desde os tempos de faculdade.

A Bárbara, Edzira, Jacira, Jorge, Luci, Lúcia, Márcia, Marileide e Ofélia, funcionárias da Clínica de Otorrinolaringologia do HCFMUSP que, sempre com muita gentileza, me auxiliam desde os tempos da residência.

Aos meus familiares pelo apoio e suporte durante todos os obstáculos enfrentados nos anos de minha formação. A meus irmãos, Meiri e Leonardo, pelo apoio constante em todas as situações.

Ao cadáver desconhecido. 
Esta tese está de acordo com as seguintes normas, em vigor no momento desta publicação:

Referências: adaptado de International Committee of Medical Journals Editors (Vancouver)

Universidade de São Paulo. Faculdade de Medicina. Serviço de Biblioteca e Documentação. Guia de apresentação de dissertações, teses e monografias. Elaborado por Anneliese Carneiro da Cunha, Maria Julia de A. L. Freddi, Maria F. Crestana, Marinalva de Souza Aragão, Suely Campos Cardoso, Valéria Vilhena. 2a ed. São Paulo: Serviço de Biblioteca e Documentação; 2005.

Abreviaturas dos títulos dos periódicos de acordo com List of Journals Indexed in Index Medicus. 


\section{SUMÁRIO}

Lista de figuras

Lista de abreviaturas e siglas

Lista de símbolos

Resumo

Summary

Instructions to authors

Artigo

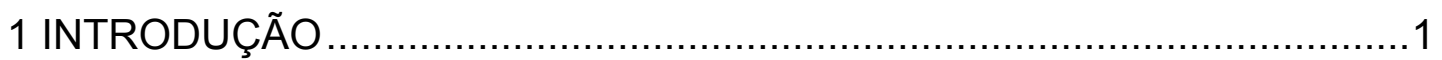

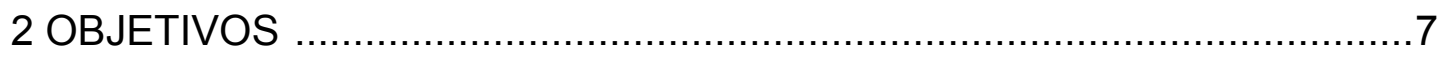

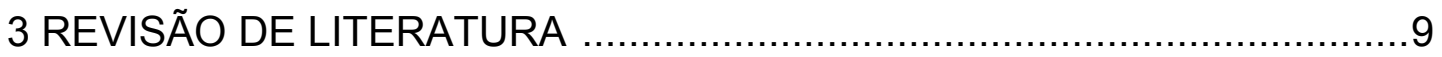

3.1 Aspectos gerais sobre o tecido conjuntivo ....................................10

3.1.1 As fibras do sistema elástico ................................................. 11

3.1.1.1 Biossíntese e caracterização dos diferentes tipos de fibras do

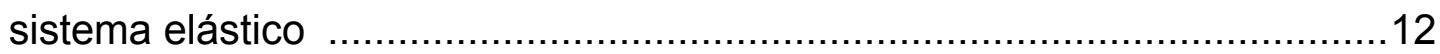

3.1.1.2 Distribuição diferencial e características funcionais das fibras

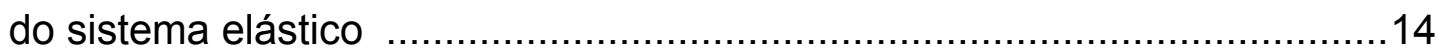

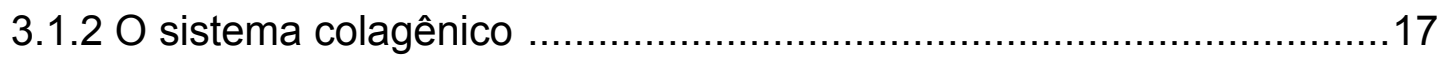

3.2 Estrutura histológica da lâmina própria de pregas vocais de adultos .....20

3.3 Estrutura histológica de pregas vocais de fetos, neonatos e crianças ....24

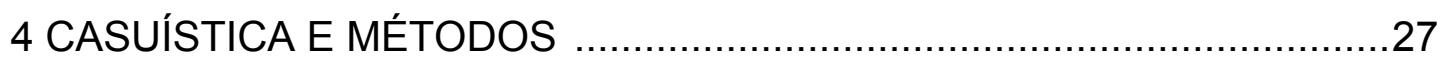

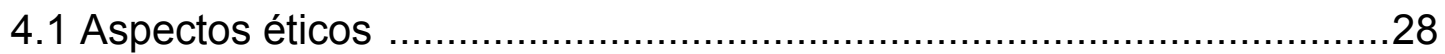

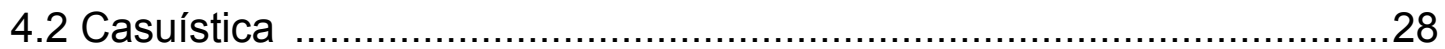

4.3 Métodos para estudo em microscopia de luz ...................................31

4.3.1 Método da Hematoxilina-Eosina .................................................. 31

4.3.2 Método da Picrossírius-Polarização ............................................... 31

4.3.3 Método de Resorcina-Fucsina de Weigert com prévia oxidação

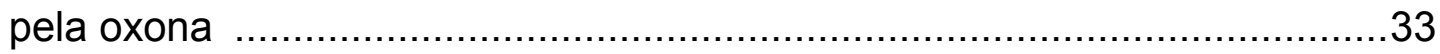

4.4 Método para estudo em microscopia eletrônica de transmissão ...........34

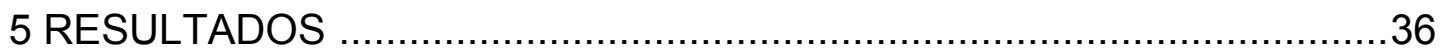

5.1 Distribuição das fibras dos sistemas colagênico e elástico ...................37 
5.2 Aspecto ondulado das fibras de colágeno 39

5.3 Interação entre as células e as fibras da matriz extracelular 40

6 DISCUSSÃO .51

7 CONCLUSÕES 62

8 REFERÊNCIAS 64 Apêndice 


\section{LISTA DE FIGURAS}

Figura 1 - Processamento do material de estudo 30

Figura 2 - Corte histológico horizontal de prega vocal direita de feto de oito meses, corado com HE

Figura 3 - Micrografia de corte histológico equivalente ao da figura dois observado em maior aumento

Figura 4 - Corte histológico adjacente ao da figura 2 corado com Picrossírius e observado com luz convencional

Figura 5 - Corte histológico adjacente ao da figura 2 corado com Picrossírius e observado sob polarização

Figura 6 - Corte histológico equivalente ao da figura 5 em maior aumento 43

Figura 7 - Corte histológico horizontal de prega vocal de feto de 8 meses, corado com Resorcina-fucsina com oxidação prévia

Figura 8 - Corte histológico coronal de região intermacular de prega vocal de feto de 7 meses, corado com Resorcina-fucsna com oxidação prévia

Figura 9 - Micrografia de outra região do mesmo corte da figura 8 .

Figura 10 - Corte histológico horizontal de prega vocal de feto de 9 meses corado com Resorcina-fucsina com oxidação prévia......45

Figura 11 - Micrografia de outra região do mesmo corte da figura 10 45

Figura 12 - Micrografia eletrônica da região superficial da lâmina própria de prega vocal de feto de 9 meses 
Figura 13 - Micrografia eletrônica de outro fragmento da mesma prega

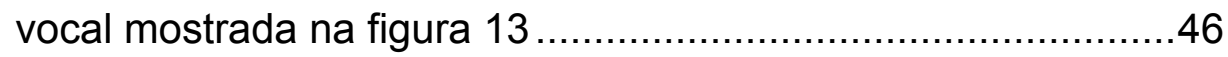

Figura 14 - Micrografia eletrônica de grande aumento ...............................47

Figura 15 - Micrografia eletrônica de um fragmento de lâmina própria

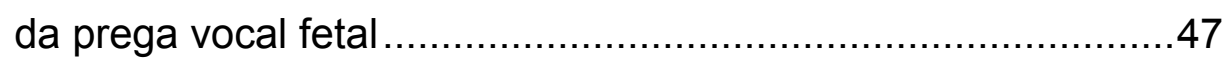

Figura 16 - Corte histológico horizontal de prega vocal de feto de 8 meses, corado com Picrossírius, observado com luz convencional

Figura 17 - Micrografia eletrônica de prega vocal de feto de 8 meses .48

Figura 18 - Micrografia eletrônica de grandíssimo aumento obtida de prega vocal de feto de 9 meses

Figura 19 - Micrografia eletrônica de grande aumento de prega vocal de feto de 8 meses. 49

Figura 20 - Micrografia eletrônica de prega vocal de feto de 9 meses .50

Figura 21 - Micrografia eletrônica de região superficial da prega vocal de feto de 9 meses. 


\section{LISTA DE ABREVIATURAS E SIGLAS}

$\begin{array}{ll}\text { CAPPesq } & \text { Comissão para Análise de Projetos de Pesquisa } \\ \text { FMUSP } & \text { Faculdade de Medicina da Universidade de São Paulo } \\ \text { F } & \text { Feminino } \\ \text { HC } & \text { Hospital das Clínicas } \\ \text { HE } & \text { Hematoxilina e Eosina } \\ \text { LIM } & \begin{array}{l}\text { Laboratório de Investigação Médica } \\ \text { M }\end{array} \\ \text { SVOC- USP } & \begin{array}{l}\text { Serviço de Verificação de Óbitos da Capital da Universidade } \\ \text { de São Paulo } \\ \text { et al. }\end{array} \\ & \begin{array}{l}\text { e outros } \\ \text { Salno }\end{array}\end{array}$




\section{LISTA DE SÍMBOLOS}

\begin{tabular}{|c|c|}
\hline$\alpha$ & alfa \\
\hline $\mathrm{cm}$ & centímetro \\
\hline $\mathrm{Da}$ & dalton \\
\hline g & grama \\
\hline $\mathrm{HCl}$ & ácido hidroclorídrico \\
\hline $\mathrm{Kb}$ & quilobite \\
\hline KV & quilovolt \\
\hline M & massa molar \\
\hline $\mathrm{mg}$ & miligrama \\
\hline $\mathrm{mL}$ & mililitro \\
\hline $\mathrm{nm}$ & nanômetro \\
\hline $\mathrm{NaCl}$ & cloreto de sódio \\
\hline $\mathrm{n}^{0}$ & número \\
\hline OsO4 & Tetróxido de ósmio anidro \\
\hline${ }^{0} \mathrm{C}$ & grau Celsius \\
\hline$\mu g$ & micrograma \\
\hline$\%$ & porcentagem \\
\hline
\end{tabular}




\section{RESUMO}

Nita LM. Estudo histoquímico e ultra-estrutural da distribuição das fibras da matriz extracelular na prega vocal humana fetal no período perinatal. Tese (doutorado). São Paulo: Faculdade de Medicina, Universidade de São Paulo; 2008.

Acredita-se que nos humanos, o ligamento vocal se desenvolva após o nascimento. No entanto, não há consenso na literatura sobre qual a faixa etária de seu aparecimento. Muitos estudos indicam que no neonato, a lâmina própria da prega vocal apresenta-se com algumas fibras esparsas sem uma organização particular. O principal objetivo deste estudo foi obter informação a respeito das fibras colagênicas e do sistema elástico (sob a luz dos conhecimentos atuais sobre a matriz extracelular), na lâmina própria de pregas vocais de fetos no período perinatal. Laringes obtidas por autópsia de fetos entre sete a nove meses foram estudadas através de microscopia de luz e eletrônica de transmissão. Fibras contendo colágeno foram identificadas através do Método da Picrossírius-polarização, fibras do sistema elástico foram descritas utilizando-se o método de Resorcina-fucsina de Weigert após oxidação com oxona. Os resultados histoquímicos coincidem com as observações da microscopia eletrônica, evidenciando populações de fibras de colágeno segregadas em diferentes compartimentos na lâmina própria. Assim, em sua região central as fibras de colágeno se mostraram finas, fracamente birrefringentes de coloração esverdeada, enquanto que as regiões superficiais e profundas apresentaram fibras grossas de colágeno com forte birrefringência de cor vermelho-amarelada, quando estudadas através do método da Picrossírius-polarização. Estas características sugerem que as fibras finas da região central são compostas principalmente por colágeno tipo III, enquanto o colágeno tipo I predomina nas regiões superficial e profunda, em concordância com as observações da literatura relacionada com o estudo da prega vocal de adultos. Assim como o 
componente colagênico, as fibras do sistema elástico mostraram uma distribuição diferencial ao longo da lâmina própria. Em certo sentido, esta distribuição é complementar àquela das fibras de colágeno: a região central, na qual fibras colagênicas eram escassas e finas, apresentou maior densidade de fibras do sistema elástico, em comparação às regiões superficial e profunda. Assim, a presença de um padrão de distribuição diferencial das fibras da matriz extracelular na prega vocal humana fetal equivalente à descrição clássica do ligamento vocal adulto nos permitiu concluir que o ligamento vocal já está presente ao nascimento. As implicações funcionais destes achados foram discutidas. O conceito corrente de que os estímulos externos, como a fonação, são essenciais para a determinação da estrutura em camadas da lâmina própria, faz com que nossos resultados sejam surpreendentes ao evidenciar a presença de uma distribuição complexa e organizada dos componentes do tecido conjuntivo na lâmina própria de pregas vocais de fetos no período perinatal. A idéia de que a contribuição genética poderia desempenhar um papel importante na organização destas camadas, independentemente do estímulo mecânico, poderia explicar melhor a presença das estruturas observadas já ao nascimento, uma vez que o mecanismo genético pode agir antes de qualquer estímulo mecânico externo, como a fonação.

Descritores: 1.Cordas vocais 2.Feto 3.Matriz extracelular 4.Ligamentos 5.Colágeno 6.Tecido elástico 7.Laringe 8.Tecido conjuntivo 


\section{SUMMARY}

Nita LM. Histochemical and ultrastructural study on the distribution of the extracellular matrix fibers in the human fetal vocal fold. Thesis. São Paulo: "Faculdade de Medicina, Universidade de São Paulo"; 2008.

It is currently believed that, in humans, the vocal ligament develops after birth. However, there is no consensus in the literature about the age of its surge. Most papers describe that in the newborn, the lamina propria shows the presence of some sparse fibers without any particular organization. The main purpose of this study was to obtain information regarding collagenous and elastic system fibers (in the light of the current knowledge on extracellular matrix) in the lamina propria of fetal vocal fold. Larynges obtained from autopsy of human fetuses aged seven to nine months were studied by means of light and electron microscopy. Collagen containing fibers were assessed by the Picrosirius-polarization method, elastic system fibers were described using Weigert's resorcin-fuchsin with previous oxidation with oxone. The histochemical results coincide with the electron microscope observations in showing collagen populations segregated into different compartments of the lamina propria. Thus, in its central region the collagen shows up as thin, weakly birefringent, greenish fibers while the superficial and deep regions consist of thick collagen fibers which display a strong birefringence of red or yellow color when studied with the aid of the Picrosirius-polarization method. These characteristics strongly suggest that the thin fibers in the central region are composed mainly of type-III collagen, whereas type-I collagen predominates in the superficial and deep regions, in agreement with the observations in the literature pertaining to studies of adult vocal folds. As well as collagen, the elastic system fibers show a differential distribution throughout the lamina propria. This distribution is complementary, in a sense, to that of the collagen fibers: the central region, with thin collagenous fibers, presents the greatest density of elastic system fibers in comparison to the superficial and deep regions. Thus, the presence of a 
differential distribution of the extracellular matrix fibers in the fetal vocal fold equivalent to the classical description of the adult vocal ligament allowed the conclusion that a vocal ligament is already present in the newborn. The functional implications of the foregoing findings are discussed. Current ideas sustaining that stimuli like phonation are essential to the determination of the layered structure of the lamina propria would make it surprising that a newborn baby could present a complex and organized distribution of connective tissue components as our results show to be the case. The idea that genetic contrivance instead should play a role in the organization of these layers seems to explain better the observed structures once it would act before any mechanical stimulus similar to phonation could take place.

Descriptors: 1.Vocal cords 2.Fetus 3.Extracellular matrix 4.Ligaments 5.Collagen 6.Elastic tissue 7.Larynx 8.Connective tissue 


\section{Journal of Anatomy}

Published on behalf of the Anatomical Society of Great Britain and Ireland

Edited by:

Gillian Morriss-Kay

Print ISSN: 0021-8782

Online ISSN: $1469-7580$

Frequency: Monthly

Current Volume: 210 / 2007

ISI Journal Citation Reports ${ }^{\circ}$ Ranking: 2006: 2/15 (Anatomy \& Morphology)

Impact Factor: 2.458

Author Guidelines

\section{EXCLUSIVE LICENCE FORM}

Authors are required to sign an exclusive licence form (ELF) granting the Anatomical Society of Great Britain and Ireland exclusive publishing rights for all papers accepted for publication. Signature of the ELF is a condition of publication and papers will not be passed to the publisher unless a signed form has been received. Signature of the ELF does not affect ownership of copyright in the material. After publication authors retain the right to publish their paper in various medium/ circumstances (please refer to the form for more information). The ELF can be downloaded from the JAnat online submission website or here.

Production will not start on your paper until we are in receipt of a signed exclusive licence form.

Government employees need to complete the AUTHOR WARRANTY sections, although copyright in such cases does not need to be assigned. For multi-author papers, it is the responsibility of the corresponding author to submit a signed ELF, on behalf of all contributors.

OPEN ACCESS SERVICE

OnlineOpen is a pay-to-publish service from Blackwell that offers authors whose papers are accepted for publication the opportunity to pay up-front for their manuscript to become open access (i.e. free for all to view and download) via the Blackwell Synergy website. Each OnlineOpen article will be subject to a one-off fee of $£ 1300$ (equivalent to $\$ 2600$ ) to be met by or on behalf of the Author in advance of publication. Upon online publication, the article (both full-text and PDF versions) will be available to all for viewing and download free of charge. The print version of the article will also be branded as OnlineOpen and will draw attention to the fact that the paper can be downloaded for free via the Blackwell Synergy service.

Any authors wishing to send their paper OnlineOpen will be required to complete the combined payment and copyright licence form available from our website here.

(Please note this form is for use with OnlineOpen material ONLY.)

Once complete this form should be sent to the Editorial Office along with the rest of the manuscript materials at the time of acceptance or as soon as possible after that (preferably within 24 hours to avoid any delays in processing). Prior to acceptance there is no requirement to inform an Editorial Office that you intend to publish your paper OnlineOpen if you do not wish to do so.

\section{SUBMISSIONS}

\section{Pre-submission English-language editing}

Authors for whom English is a second language may choose to have their manuscript professionally edited before submission to improve the English. A list of independent suppliers of editing services can be found at www.blackwellpublishing.com/bauthor/english_language.asp. All services are paid for and arranged by the author, and use of one of these services does not guarantee acceptance or preference for publication.

Manuscripts

JAnat accepts online submission at http://mc.manuscriptcentral.com/janat. This enables the quickest possible review. Manuscript submission online can be as Word document (.doc) or RTF (.rtf). If submitting to Manuscript Central using LaTeX please upload a PDF file of the manuscript for the reviewers. Note that upon acceptance we will require your TeX/LaTeX source files to edit and typeset the article. Figures for review should be uploaded separately as GIF (.gif), JPEG (.jpg), TIFF (.tif), or EPS (.eps). On acceptance, you will be required to provide HIGH RESOLUTION GRAPHICS FILES (note that GIF (.gif), JPEG (.jpg), and PNG (.png) files are not acceptable for publication). Full upload instructions and support are available online from the submission site via the Get Help Now button. Please submit your covering letter or comments to the Editor in Chief when prompted online.

\section{Word 2007}

Will authors please note that Word 2007 is not yet compatible with journal production systems. Unfortunately, the journal cannot accept Microsoft Word 2007 documents until such time as a stable production version is released. Please use Word's 'Save As' option therefore to save your document as an older (.doc) file type. 


\section{Revisions}

Revised manuscripts must be submitted in their final form, within 2 months of authors being notified of conditional acceptance (pending satisfactory revision). Resubmissions after this time will be considered as new.

\section{PRESENTATION}

Text

Text should be divided into the following sections and appear in the order:

(1) title page (with short running page heading, title, authors names and affiliations);

(2) summary;

(3) keywords;

(4) introduction;

(5) main body;

(6) concluding remarks;

(7) acknowledgements;

(8) references;

(9) supplementary material;

(10) tables; and

(11) figure legends.

Authorities for the latin binomial of every organism are not used in the title or summary, and only on the first mention in the main body of the text.

Gene names and loci should be italic, proteins should be roman.

Virus nomenclature (and acronyms) should follow the guidelines of the International Committee on the Taxonomy of Viruses (ICTV). The current report is: van Regenmortel MHV, Fauquet CM, Bishop DHL (Eds) (2001) Virus Taxonomy: Seventh Report of the International Committee on Taxonomy Viruses. San Diego: Academic Press. Authors are also advised to check the ITCV website for the latest information.

Chemical nomenclature should follow the International Union of Pure and Applied Chemistry (IUPAC) definitive rules for nomenclature.

Industrial products should be referred to by their common names (ISO Publications 1831, 2474, etc.). In the absence of a common name, use the full name or a defined abbreviation, in preference to a trade name. At first mention, trade names should be capitalised.

Statistics: Calculations and the validity of deductions made from them should be checked and validated by a statistician.

Symbols, units and abbreviations should be expressed as Système International (SI) units, as given in: Baron DN (Ed) (1994) Units and Abbreviations: a guide for medical authors and editors. London: Royal Society of Medicine Press. In exceptional circumstances, others may be used, provided they are consistent. Apply to the Editorial Office for advice.

\section{References}

References in the text should be inserted in parentheses in full for single and dual authored papers, but using the first author and et al. for multiple authored papers. Reference to personal communications, unedited and un-refereed work, and work that is unpublished should be minimal and should appear in the text only. It is the author's responsibility to obtain permission from colleagues to include their work as a personal communication.

References in the list should follow the Harvard system. Over 6 authors will be abbreviated to 3 authors et al. Refer to a recent copy of the journal for examples.

We recommend the use of a tool such as EndNote or Reference Manager for reference management and formatting.

EndNote reference styles can be searched for here.

Reference Manager reference styles can be searched for here.

\section{Supplementary Material}

Quantitative biological data too extensive for inclusion in the print edition of the journal may be presented in the online edition, as supplementary material (supp. mat.). As such, it will be reviewed as an integral part of the paper. The availability of supp. mat. should be indicated in the main manuscript by a paragraph, to appear after the references, providing titles of figures, tables, etc. There are guidelines regarding supplementary material here.

\section{Graphics}

Numerical results should be presented either as tables or figures, but not both. The journal welcomes colour figures and plates, when information would be lost if reproduced in black and white.

Tables: Tables should be typed on separate pages, as an integral part the text file. They should have a brief descriptive title and be self-explanatory. Units should appear in parentheses in the column headings, not in the body of the table. Repeated words or numerals on successive lines should be written in full. Footnotes should be minimal. When the precision of data is expressed as standard error (se) or standard errors of differences (sed) the degrees of freedom (df) should be given. 
Electronic artwork: JAnat only accepts submission of electronic artwork. The journal accepts the following formats only:

(1) GRAPHS, CHARTS and MAPS as Encapsulated Postscript Format (.eps).

The best results are obtained with software applications that can output EPS format (Systat SigmaPlot;

Adobe Illustrator; CorelDraw; Deneba Canvas; Macromedia Freehand); and

(2) PHOTOGRAPHS in Tagged Image File Format (.tif).

TIFF files should be supplied at a minimum resolution of $300 \mathrm{dpi}$ (dots per inch) at the final size at which they are to appear in the journal. TIFF and EPS formats are the industry standard for archiving and print and online publication.

Detailed information on digital illustration standards is available at this webpage.

Please note that file formats other than EPS and TIF will be automatically rejected by the online submission website.

Colour files should be in CMYK format. Labelling should be in 10pt sans serif style font. Figure sections should be designated with upper case letters. Magnification bars should be given on electron and light micrographs.

Original artwork: If you are unable to submit electronic artwork, please provide two sets of all figures as high-quality glossy prints at the size that they are to appear in print. One set should be unlabelled.

Legends: Table and figure legends should be included within the text file and contain sufficient information to be understood without reference to the text. Each should begin with a short title for the figure. All symbols and abbreviations should be explained within the legend.

Cover images: Electronic artwork of high quality suitable for the cover of JAnat are welcomed. They should be sent to the Editorial Office and be accompanied by a relevant caption. It is preferred that images should be related to submitted papers. Contributors are required to grant exclusive publishing rights to the Society. It is the Publisher's policy not to publish items without signed exclusive licence forms.

\section{PLAGIARISM}

Authors must obtain permission to reproduce any copyright material, and include an acknowledgement of the source in their Article. Authors should be aware that the unreferenced use of the published and unpublished ideas, writing or illustrations of others, from whatever source (including research grant applications), or submission of a complete paper under "new" authorship in the same or a different language, constitutes plagiarism.

\section{CONDITIONS OF ACCEPTANCE}

Manuscripts are accepted on the understanding that they will not be published elsewhere in any form, without the prior consent of the Society. Your material will not be passed to the Publisher without receipt of:

1. covering letter documenting any revisions required by the editor;

2. signed exclusive licence form;

3. completed accepted artwork checklist - documenting the graphic files supplied in accordance with industry standards; and

4. EPS files output from vector based software/ 800dpi TIFF files. LOW RESOLUTION ARTWORK SUBMITTED FOR REVIEW IS NOT SUITABLE FOR PRINT OR ONLINE PUBLICATION.

\section{ARTICLE TRACKING}

NEW: Online production tracking is now available for your article through Blackwell's Author Services. Author Services enables authors to track their article - once it has been accepted - through the production process to publication online and in print. Authors can check the status of their articles online and choose to receive automated e-mails at key stages of production. The author will receive an e-mail with a unique link that enables them to register and have their article automatically added to the system. Please ensure that a complete e-mail address is provided when submitting the manuscript. Visit Blackwell's Author Services for more details on online production tracking and for a wealth of resources including FAQs and tips on article preparation, submission and more.

PROOFS

Email notification that your work is in proof and ready for collection will be sent from the JAnat eproofing website. Further instructions will be sent with the upload notification email. Acrobat Reader is required in order to read this file. This can be downloaded (free of charge) from Adobe.

In your absence, please arrange for a colleague to correct on your behalf. Major alterations will be charged to the author and delay publication.

\section{OFFPRINTS}

A PDF is provided upon publication to the corresponding author. Paper offprints can be purchased prior to print publication from COS Printers.

\section{AUTHOR MATERIAL ARCHIVE POLICY}

Please note that unless specifically requested, Blackwell Publishing will dispose of all hardcopy or electronic material submitted two months after publication. If you require the return of any material submitted, please inform the editorial office or production editor as soon as possible if you have not yet done so. 
THE PRESENCE OF A VOCAL LIGAMENT IN FETUSES: A HISTOCHEMICAL AND ULTRASTRUCTURAL STUDY

\begin{tabular}{|r|l|}
\hline Journal: & Journal of Anatomy \\
\hline Manuscript ID: & JANAT-2008-0026 \\
\hline Manuscript Type: & Original Paper \\
\hline Author: & 16 -Jan-2008 \\
\hline Complete List of Authors: & $\begin{array}{l}\text { Nita, Luciana; University of São Paulo School of Medicine, } \\
\text { Department of Otolaryngology } \\
\text { Battlehner, Claudia; University of São Paulo School of Medicine, } \\
\text { Laboratory for Cell Biology, Department of Pathology } \\
\text { Ferreira, Marcelo; University of São Paulo School of Medicine, } \\
\text { Laboratory for Cell Biology, Department of Pathology } \\
\text { Imamura, Rui; University of São Paulo School of Medicine, } \\
\text { Department of Otolaryngology } \\
\text { Sennes, Luiz; University of São Paulo School of Medicine, } \\
\text { Department of Otolaryngology } \\
\text { Caldini, Elia; University of São Paulo School of Medicine, Laboratory } \\
\text { for Cell Biology, Department of Pathology } \\
\text { Tsuji, Domingos; University of São Paulo School of Medicine, } \\
\text { Department of Otolaryngology }\end{array}$ \\
\hline Key Words: & $\begin{array}{l}\text { Vocal cord, Vocal ligament, Fetuses, Extracellular matrix, Collagen, } \\
\text { Elastic fibre, Ultrastructure }\end{array}$ \\
\hline \hline
\end{tabular}

\section{(1) ScholaroNE Manuscript Central}




\section{Introduction}

Phonation is a complex phenomenon that involves many different systems. The voice is produced through vibration of vocal folds and modified by the resonance of supraglottic vocal tract. However, the initial stage of vocal production is a purely mechanical phenomenon, directly dependent on appropriate vibration of vocal folds.

Since Hirano (1974) described the layered structure of the vocal fold lamina propria (superficial, intermediate and deep layer), many studies have been carried out to better understand the structural organization of the extracellular elements in the lamina propria of the vocal fold, both by means of light and electron microscopy. It is known that the distribution of extracellular matrix collagenous and elastic fibres is directly related with viscoelastic and biomechanical properties the vocal folds, with functional implications. (Gray et al., 2000).

Despite the extensive literature about the structure of lamina propria of vocal folds in adults, there are few studies in children and neonates. It was reported that there is no vocal ligament at birth (Sato \& Hirano, 1995; Ishii et al., 2000; Sato et al., 2001; Hartnick et al., 2005), but there is no agreement on what is the age which the vocal ligament as known as in adults is finally present. Lamina propria of children's vocal fold was described as entirely similar to Reinke's space (superficial layer of lamina propria) of adult vocal folds, with large amount of amorphous substance and sparse fibres that do not display a differential distribution pattern (Campos Bañales et al., 1995; Sato \& Hirano, 1995; Ishii et al., 2000; Sato et al., 2001).

However, it had been also described that, in larynges of children as young as 3 to 8 months, the small amount of collagen fibres of the lamina propria is distributed into two 
layers, such as in adults: one layer was located immediately beneath the epithelium and the other one located in the zone adjacent to the vocal muscle (Hammond, 2000).

Despite this controversy about the distribution of extracellular matrix components of vocal fold lamina propria, it has been properly demonstrated that after birth, it continues its process of development and maturation up to the highly complex structure of adult vocal fold, under exogenous stimuli, mainly phonation (Hartnick et al., 2005).

Based on these observations, we hypotese that it would be important to describe, in the light of current knowledge of the ultrastructural patterns and the histochemical proprieties of the elastic and collagenous systems fibres, the structural organization of the lamina propria of the fetal vocal fold in the perinatal period.

\section{Methods}

\section{Tissue collection}

The protocol was approved by ethics committee of the Hospital das Clínicas, Medical School, University of São Paulo. Eighteen human larynges excised from $7^{\text {th }}$ to $9^{\text {th }}$ month fetus within 24 hours post-mortem were obtained during necropsies. In this study we included anatomic pieces without noticeable macroscopic affections in the area of the larynx and without macerated cells from individuals free of apparent congenital disorder. Each larynx was sagitally sectioned and the two hemilarynges were immediately immersed in the appropriate fixative. 


\section{Light microscopy}

Tissues were fixed in $4 \%$ neutral, phosphate-buffered, paraformaldehyde for $6 \mathrm{~h}$ at room temperature, dehydrated in graded concentrations of alcohol, embedded in paraffin.

Randomly chosen right or left vocal folds were horizontally or coronally sectioned at 5 $\mu \mathrm{m}$. Serial sections were stained with hematoxylin and eosin (H\&E), Picrosiriushematoxylin (Junqueira et al., 1978) and Weigert's resorcin-fuchsin with previous oxidation with oxone (Caldini et al., 1990).

When the Picrosirius-stained slides are observed with the aid of polarization microscopy, the method becomes specific for oriented collagen molecules, in the sense that only these structures present an enhancement of their natural birefringence when observed under polarized light (Junqueira et al., 1978).

All three types of elastic system fibres (oxytalan, elaunin and the elastic fibre proper) are stained when the tissue is oxidized prior to staining by Weigert's resorcin-fuchsin (Battlehner et al., 2003).

\section{Electron microscopy}

Specimens obtained from the lamina propria region of the vocal folds were fixed in $2 \%$ glutaraldehyde dissolved in $0.15 \mathrm{M}$ phosphate buffer at $\mathrm{pH} 7.2$ for $1 \mathrm{~h}$, followed by postfixation in $1 \%$ osmium tetroxide dissolved in $0.9 \%$ sodium chloride for $1 \mathrm{~h}$. Fixed material was stained in block in $0.5 \%$ aqueous uranyl acetate overnight. After this procedure, the samples were dehydrated in graded acetone series, and embedded in Araldite resin. Ultrathin sections, at 70nm were obtained by using a diamond knife at an LKB ultratomicrotome, placed on 200-mesh copper grids and double-stained by uranyl 
acetate and lead citrate. The grids were studied and micrographed in a Jeol 1010 transmission electron microscope operating at $80 \mathrm{kV}$.

\section{Results}

Our observation on the structure of the fetal vocal fold confirmed the descriptions available in the literature. The coronal and horizontal sections show that the normal vocal fold may be described as a structure formed by different tissues which, from the lumen to deeper regions, comprises: (1) the lining epithelium, (2) the lamina propria and (3) the skeletal muscle layer. The lamina propria is the connective tissue between the basal lamina of the epithelium and the vocal muscle. When studied with H\&E staining it was not possible to identify any pattern of extracellular matrix fibres distribution through the entire lamina propria (Fig. 1A).

Slides stained with Picrosirius were carefully examined under polarized light. With this method, the thickness of the fibre determines its color of birefringence. Thick fibres are yellow to red and thin fibres appear as greenish structures. The vocal fold lamina propria studied by the Picrosirius polarization method showed the presence of two distinct collagen populations segregated into different compartments: the collagen in the central region showed up as thin, weakly birefringent greenish fibres, contrasting with the subepithelial and the deep region where strongly birefringent, thick, yellow to red fibres could be seen; these fibres were arranged in parallel to the major axis of the vocal fold (Figs. 1B and 1C).

After careful examination of the slides stained by Weigert's resorcin-fuchsin with previous oxidation, it was possible to describe the distribution of the elastic system fibres. 
They were distributed through all the lamina propria of fetal vocal fold, presenting two regions of higher densities: (1) a well delimited region in the central zone of lamina propria rich in elastic fibres, and (2) a palisade of thick fibres was visible just beneath the epithelial basement membrane; their orientation is such that they are roughly parallel to the long axes of the vocal fold (Figs. 2A and 2B).

Ultrathin sections confirmed that the lamina propria of vocal folds contains both extracellular matrix fibrillar components: fibres of the elastic system appear interspersed with fibrils of the collagenous system. The fibrillar elements of both systems are disposed parallel to the long axis of the vocal fold. The conspicuous presence of fibroblasts (that characteristically exhibit long cytoplasmic processes) was often observed among the fibres of the elastic system and the collagenous fibrils. It was also possible to identify a great quantity of elastic system fibres in the central regions of the lamina propria of fetal vocal fold (Fig. 3). These fibres correspond to those that markedly reacted when observed under the light microscope in the preparations stained by Weigert's resorcin-fuchsin method.

The collagen fibres found in the lamina propria of fetal vocal folds resembled typical collagen fibres of connective tissues. These fibres consist of parallel arrays of collagen fibrils. Longitudinal aspects of collagenous fibres revealed their profile as a slight undulating course (crimp). (Figs. 4A and 4B)

\section{Discussion}

The main purpose of this study was to obtain information regarding collagenous and elastic system fibres (in the light of the current knowledge on extracellular matrix) in the 
lamina propria of fetal vocal fold. The histochemical results coincide with the electron microscope observations in showing collagen populations segregated into different compartments of the lamina propria. Thus, in its central region the collagen shows up as thin, weakly birefringent, greenish fibres while the superficial and deep regions consist of thick collagen fibres which display a strong birefringence of red or yellow color when studied with the aid of the Picrosirius polarization method. These characteristics strongly suggest that the thin fibres in the central region are composed mainly of type-III collagen, whereas type-I collagen predominates in the superficial and deep regions, in agreement with the observations in the literature pertaining to studies of adult vocal folds. (Melo et al., 2003; Tateya et al., 2005).

As well as collagen, the elastic system fibres show a differential distribution throughout the lamina propria. This distribution is complementary, in a sense, to that of the collagen fibres: the central region, with thin collagenous fibres presents the greatest density of elastic system fibres in comparison to the superficial and deep regions.

Classically, the histological structure of the newborn and infant vocal folds is described as different from that of the adults: the entire lamina propria appears as a uniform structure. However, under polarization microscopy, we could observe strong birefringence in the upper region of the lamina propria and in the adjacent zone to vocal muscle in the newborn vocal fold, suggesting the high content of collagenous fibres. In opposite, the middle region appears weakly birefringent, suggesting a small amount of collagen. These findings are consistent with our observation of the relative great amount of elastic system fibres in the middle region of lamina propria, forming the elastic portion of the vocal ligament. 
The compounds of amorphous fundamental substance, mainly represented by proteoglycans, glycoproteins and water, together with elastic fibres, directly affect tissue viscosity and promote the absorption of the impact shock between vocal folds during vibration. Collagen component, in turn, is responsible for maintaining structural resistance. The division of lamina propria in layers is based on differential distribution of these fibrous elements (Hammond et al., 1997; Sato et al., 2001).

It is difficult to determine the individual contributions of biological components to mechanical property. As connective tissues have a predominantly mechanical function it is of importance to understand how the constituent chemical components (collagen, glycosaminoglycans, elastic fibres, minerals, water) provide the tissue with its mechanical attributes. These attributes, however, vary markedly among different connective tissues. For instance, tendon has high collagen content, orientated fibrils, and a low glycosaminoglycan content. Other specialized tissues, such as the ligamentum nuchae, are rich in elastic fibres and their mechanical properties are greatly influenced by this component (Parry \& Craig, 1988). In terms of their mechanical role, connective tissues must have some appropriate combination of two basic attributes - an ability to withstand high tensile or compressional stresses and the ability to recover shape and form when stresses are removed.

Our results were different from those in the literature for some reasons: (1) we used horizontal sections, in order to analyze the vocal fold in its entire anterior-posterior extension, from its connection to the thyroid cartilage to the insertion in the vocal fold of thyroid cartilage, and (2) the histochemical methods used in this study had not been applied to analyze the fibres of extracellular matrix of the vocal folds of fetuses. 
For elastic system fibres identification, the Verhoeff's method describes selectively elastic fibres proper, but elaunin and oxytalan fibres are not stained. Conversely, Weigert's resorcin-fuchsin method is more sensitive and it stains elaunin fibres as well. Oxytalan fibres remain undetectable unless they are submitted to oxidation first. As to collagen system fibres, Mallory, Masson and van Gieson methods have been used, but they do not identify reticular fibres nor collagen in basal membrane. Sirius red, an acid staining substance, strongly reacts with collagen molecules, because they are rich in basic amino acids. In addition to strong reaction, the staining molecule is a long molecule that promotes intensification of its natural birefringence because many staining molecules are aligned parallel to the longitudinal axis of each collagen molecule (Montes, 1996). Thus, we used in this study histochemical methods that enable the identification of the three types of fibres of elastic system and fibrillar collagen, whose findings were confirmed by transmission electron microscopy. Current ideas sustaining that stimuli like phonation are essential to the determination of the layered structure of the lamina propria would make it surprising that a newborn baby could present a complex and organized distribution of connective tissue components as our results show to be the case. The idea that genetic contrivance instead should play a role in the organization of these layers seems to explain better the observed structures once it would act before any mechanical stimulus similar to phonation could take place. 


\section{References}

Battlehner CN, Caldini EG, Pereira JCR, Luque EH, Montes GS (2003) How to measure the increase in elastic system fibres in the lamina própria of the uterine cervix of pregnant rats. J. Anat. 203: 405-418.

Campos Bañales ME, Pérez Piñero P, Rivero J, Ruíz Casal E, López Aguado D (1995) Histological structure of the vocal fold in the human larynx. Acta otolaryngol. (Stockh). 115: 701-704.

Caldini EG, Caldini N, De-Pasquale V, Strocchi R, Guizzard S, Ruggeri S, Montes GS (1990) Distribution of elastic system fibres in the rat tail tendon and its associated sheaths. Acta Anat. 139: 341-348.

Gray SD, Titze IR, Alipour F, Hammon TH (2000) Biomechanical and histologic observations of vocal fold fibrous proteins. Ann Otol Rhinol Laryngol. 109, 77-85.

Hammond TH, Zhou R, Hammond EH, Pawlak A, Gray SD (1997) The intermediate layer: a morphologic study of the elastin and hyaluronic acid constituents of normal human vocal folds. J Voice. 11 (1): 59 - 66.

Hammond TH (2000) Age- and gender-related collagen distribution in human vocal folds. Ann Otol Rhinol Laryngo. 109, 913-920.

Hartnick CJ, Rehbar R, Prasad V (2005) Development and maturation of the pediatric human vocal fold lamina propria. Laryngoscope. 115, 4-15.

Hirano M.(1974) Morphological structure of the vocal fold as a vibrator and its variations. Folia Phoniat. 26, 89-94. 
Ishii K, Yamashita K, Akita M, Hirose H (2000) Age-related development of the arrangement of connective tissue fibres in the lamina propria of the human vocal fold. Ann Otol Rhinol Laryngol. 109, 1055-1064.

Junqueira, LCU, Cossermelli W, Brentani R (1978) Differential staining of collagens type I, II and III by sirius red and polarization microscopy. Archm. Histol. Jap. 41, $267-274$.

Melo ECM, Lemos M, Ximenes Filho JA, Sennes LU, Saldiva PHN, Tsuji DH (2003) Distribution of collagen in the lamina propria of the human vocal fold. Laryngoscope. 113 (12): $2187-2191$.

Montes GS (1996) Structural biology of the fibres of the collagenous and elastic systems. Cell Biol Int. 20 (1): $15-27$.

Parry DAD, Craig AS (1988) Collagen fibrils during development and maturation and their contribution to the mechanical attributes of connective tissue. In: Nimni ME (ed.) Collagen. Vol II. Boca-Raton, CRC Press, p.1-23.

Sato K, Hirano M (1995) Histologic investigation of the macula flava of the human newborn vocal fold. Ann. Otol. Rhinol. Laryngol. 104: 556-562.

Sato K, Hirano M, Nakashima T (2001) Fine structure of the human newborn and infant vocal fold mucosae. Ann. Otol. Rhinol. Laryngol. 110: 417-424.

Sato K, Hirano M, Nakashima T (2002) Age-related changes of collagenous fibres in the human vocal fold mucosa. Ann. Otol. Rhinol. Laryngol. 111: 15 - 20.

Tateya T, Tateya I, Bless DM (2005) Collagen subtypes in human vocal folds. Ann. Otol. Rhinol. Laryngol. 115: 469-476. 

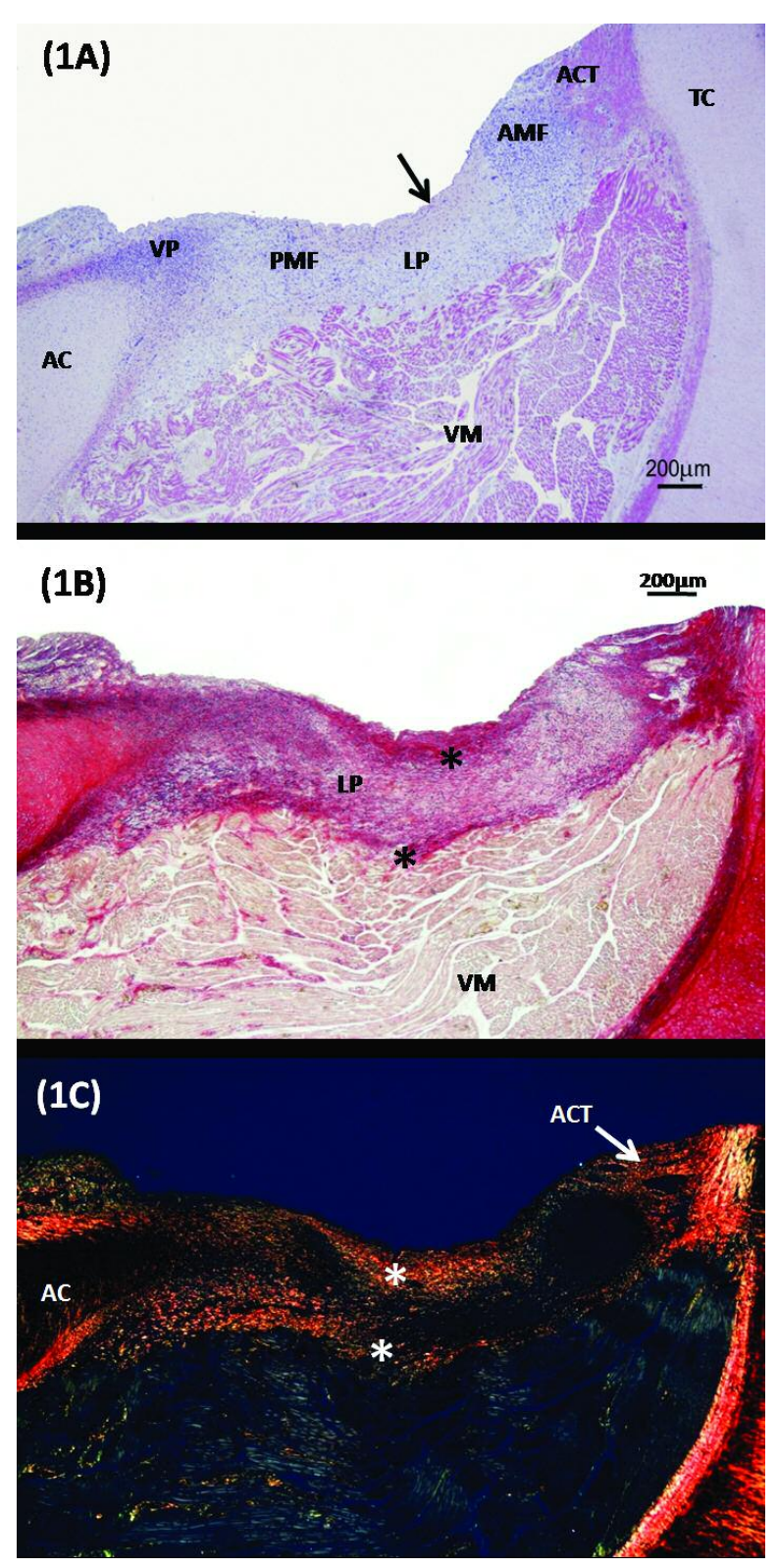

Fig. 1. Two adjacent serial horizontal sections from an 8-months-old fetus right vocal fold stained with hematoxylin-eosin (1A) or with Picrosirius shown by conventional (1B) and polarizing (1C) illumination. In $1 \mathrm{~A}$, the vocal fold can be seen in its entire anteroposterior extension, from the thyroid cartilage (TC) up to the vocal process (VP) of the arytenoid cartilage (AC) and in its entire latero-medial extension, between the vocal muscle (VM) and the epithelium (black arrow). The anterior comissure tendon (ACT) can be seen, linking the vocal fold to the thyroid cartilage; observe that anterior macula flava (AMF) and posterior macula flava (PMF) are easily identified, but no 'fibres' can be distinguished as such in the lamina propria with this staining. Figures 1B and 1C are photomicrographs of the same field shown by conventional (1B) and polarizing (1C) illumination. Observe that all structures that are deeply stained with Picrosirius in the photomicrography obtained with conventional illumination (1B) are collagenous. When viewed by polarized light $(1 \mathrm{C})$, these fibres are disclosed as birefringent structures that 
shine against a dark background. In 1B, it is possible to observe the collagen fibres in the superficial and deep layers of lamina propria (LP). The central layer corresponds to an area of fibre rarefaction, where collagen is less densely packed. This is confirmed in $\mathbf{1 C}$, where it is possible to observe that the thick collagen fibres present in superficial and deep layers form strongly birefringent sheaths that are continuous with the perichondrium of the arytenoid cartilage (AC) and with the anterior commissure tendon (ACT), but in the central layer the sparse collagenous structures show up as thin, weakly birefringent, greenish fibres. 


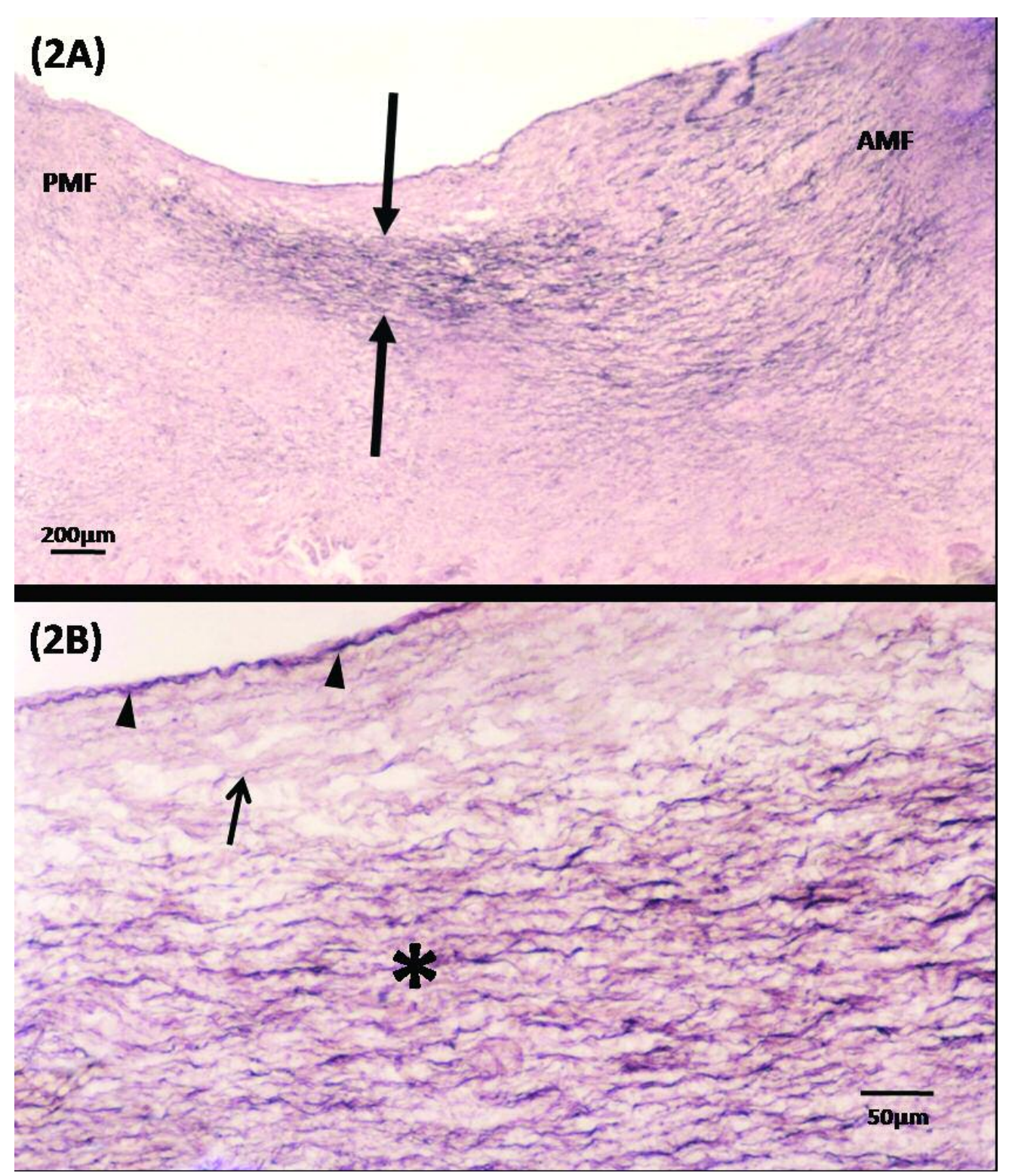

Fig. 2A - Horizontal section from an 8-months-old fetus vocal fold stained by Weigert's resorcin-fuchsin after oxidation. The elastic system fibres of fetal vocal fold are disclosed. Although they are present through all the lamina propria, it is possible to observe a sharply defined region (between arrows) rich in organized elastic system fibres that ran parallel to the major axis of the vocal fold and inserted in both anterior and posterior maculae (AMF and PMF, respectively). This region corresponds to the central layer of the lamina propria that displays sparse collagenous fibres (described in Figure 1B and 1C). The comparison of these pictures suggests that the lamina propria is not a homogeneous structure from the point of view of the distribution of collagenous and elastic system fibres. Figure 2B corresponds to a higher magnification from the same section stained for elastic system, whose fibres appear roughly parallel to the epithelial lining. Note the continuous sub-epithelial palisade of elastic system fibres (arrow heads). The superficial layer presents only a few elastic system fibres (arrow), in contrast to subjacent layer that 
shows up bundles of elastic fibres (asterisk). $142 \times 166 \mathrm{~mm}(150 \times 150 \mathrm{DPI})$ 


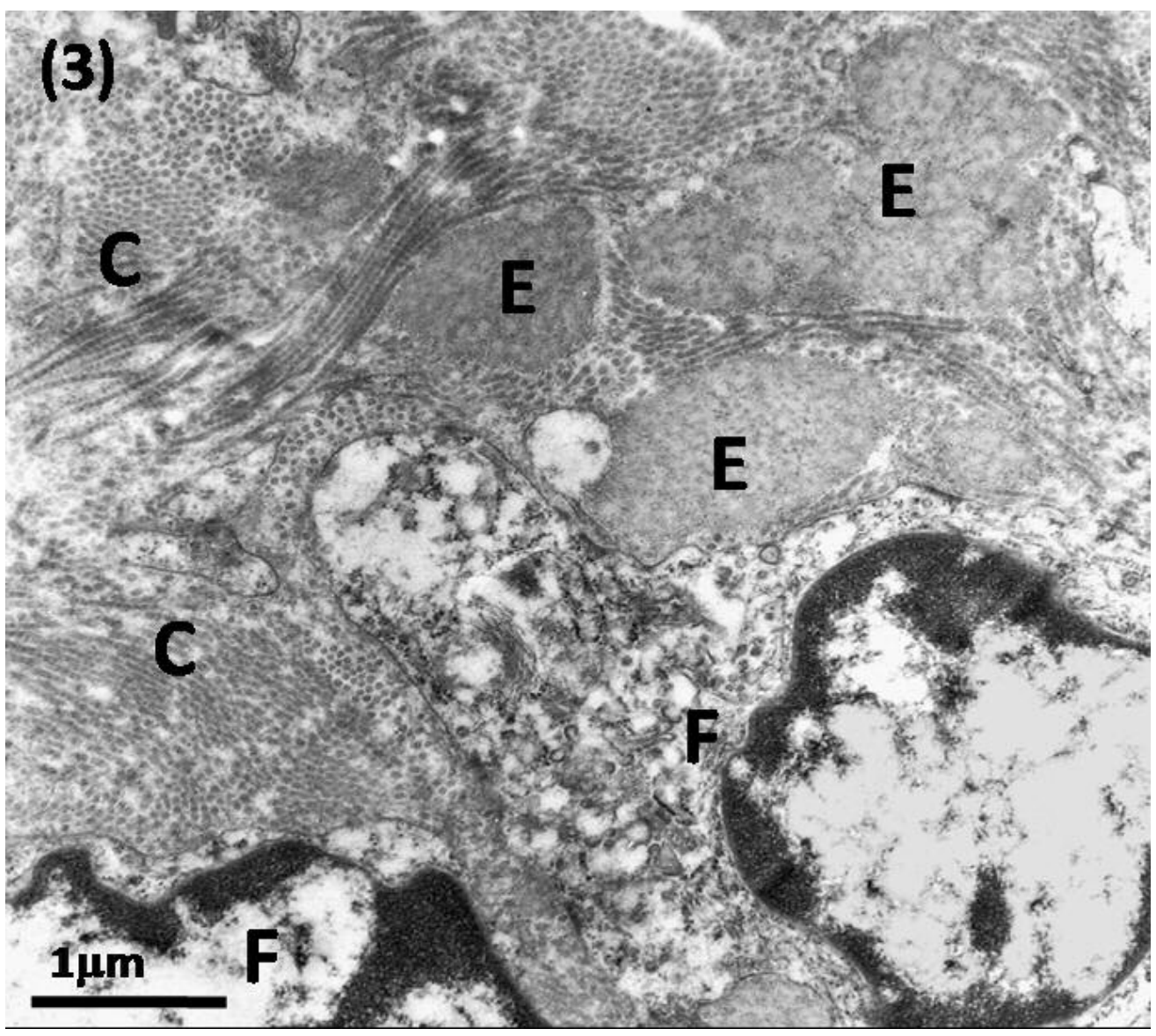

Fig. 3. Transmission electron micrograph obtained from a coronal section of an 8-monthold fetus vocal fold. This picture illustrates the abundance of fibrous elements in the extracellular matrix of the lamina propria midportion. Observe that elastic system fibres $(E)$, as well as collagen fibrils (C), appear cross-sectioned. This aspect is suggestive of a highly organized structure formed by assembled bundles distributed in the same direction, characterizing the ligamentous nature of connective tissue present in the vocal fold lamina propria of the fetuses at perinatal period. The bottom region of the picture is occupied by portions of two fibroblasts $(F)$. $116 \times 103 \mathrm{~mm}(150 \times 150 \mathrm{DPI})$ 


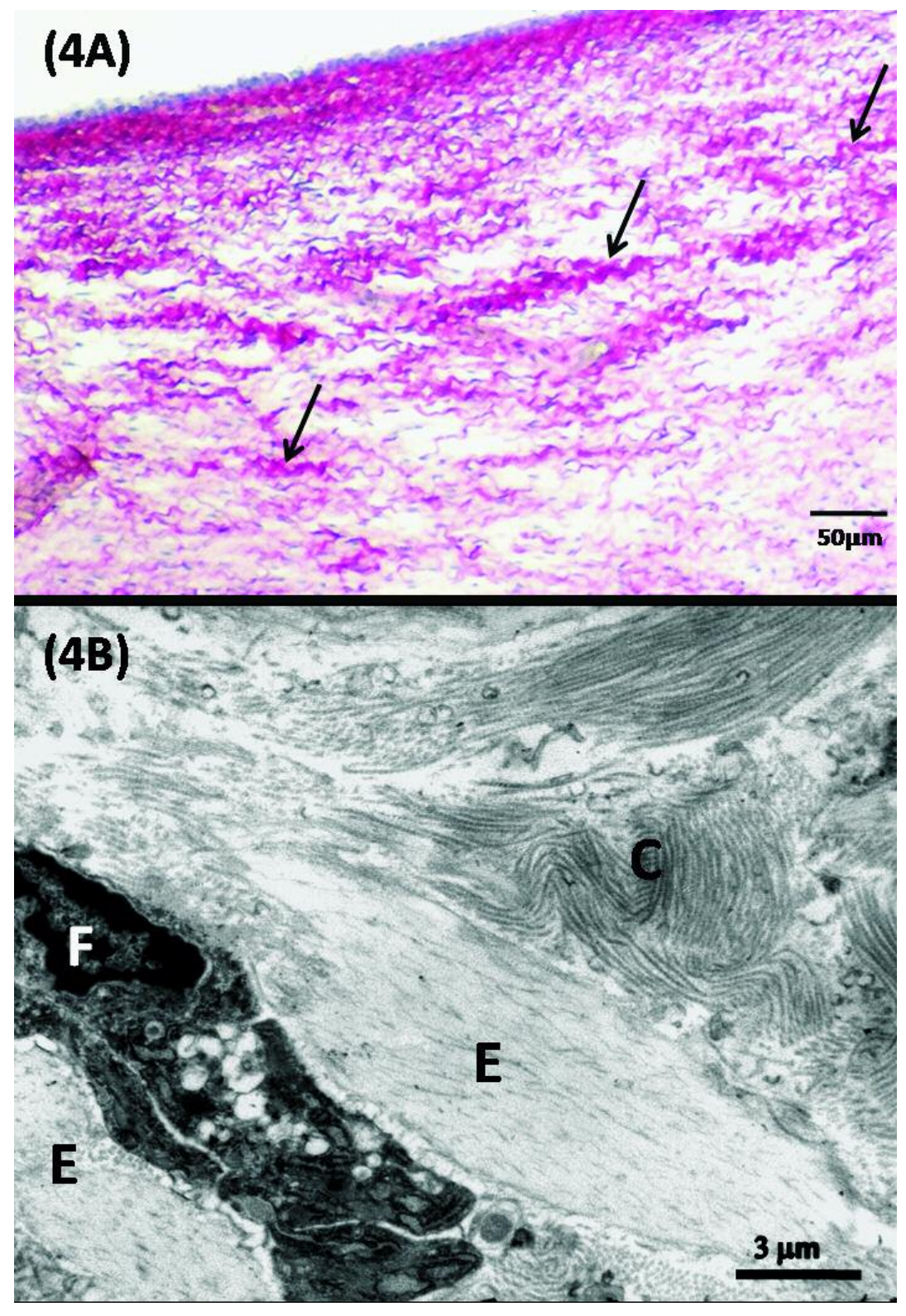

Fig. 4A. Horizontal section from a fetal vocal cord stained with Picrosirius photographed under conventional illumination. The epithelium is in the upper region. A small part of the intermacular region of lamina propria is shown. The assembled bundles formed from collagen fibres (arrows) display the same orientation (i.e. parallel to the long axis of the vocal fold). Note that the fibres present slight undulations (crimp) showing a wavy appearance. This configuration is typical in structures like tendons and ligaments. The picture 4B corresponds to an electron micrograph from a fetal vocal fold showing a fibroblast between two mature elastic fibres (E). Ultrastructurally, they are characterized by a central core of amorphous and homogeneous material (elastin) surrounded by microfibrils. The right upper region of the picture is occupied by densely packed parallel collagen fibrils $(C)$ running in the same direction and presenting an undulatly course. This profile corresponds to the ultrastructural pattern of the crimped collagen fibres pointed in 
figure 4A.

$120 \times 176 \mathrm{~mm}(150 \times 150 \mathrm{DPI})$ 
INTRODUÇÃO 


\section{INTRODUÇÃO}

A evolução filogenética da laringe possibilitou ao homem, além das funções básicas de respiração e proteção das vias aéreas, a função fonatória. Este processo evolutivo permitiu o desenvolvimento da fala, o principal meio utilizado pelo ser humano para a comunicação. É também uma capacidade do ser humano o controle extremamente fino da emissão vocal, com a produção de sons que variam em intensidade e freqüência. Todos esses processos envolvem mecanismos complexos, desde o controle pelo sistema nervoso central até o nível periférico, com a voz sendo produzida através da vibração das pregas vocais na laringe e modificada pela ressonância e articulação do trato vocal supraglótico. Porém, o estágio inicial da produção da voz é um fenômeno puramente mecânico, diretamente dependente da vibração adequada das pregas vocais (ISSHIKI et al., 1999).

Para que a vibração das pregas vocais possa ocorrer de modo adequado, é necessária uma mobilidade eficiente da mucosa. HIRANO (1974) descreveu histologicamente a estrutura em camadas da prega vocal humana (epitélio, tecido conjuntivo e músculo vocal). Além disso, propôs a divisão deste tecido conjuntivo em camada superficial, intermediária e profunda. Baseado neste modelo, HIRANO desenvolveu a teoria do complexo corpo-cobertura, segundo a qual a cobertura mucosa move-se sobre um corpo relativamente estacionário: o músculo vocal e o ligamento vocal. 
A lâmina própria corresponde ao tecido conjuntivo localizado entre o epitélio de revestimento e o músculo vocal. Este conjuntivo não é homogêneo, mas apresenta distintas regiões caracterizadas pela distribuição diferencial dos elementos constituintes da matriz extracelular. Esta compartimentalização relaciona-se diretamente com propriedades biomecânicas (GRAY, 2000; IMAMURA et al., 2003), desempenhando um papel importante no comportamento vibratório da prega vocal.

Os principais componentes da matriz extracelular são classificados de acordo com seu arranjo, formando ou não estruturas fibrilares. As proteínas fibrilares são representadas pelas fibras que constituem os sistemas colagênico (fibras colágenas e fibras reticulares) e elástico (fibras oxitalânicas, elaunínicas e elásticas propriamente ditas - aqui enumeradas em gradiente crescente de elasticidade). Já o componente não fibrilar da matriz extracelular corresponde à substância fundamental amorfa, constituída principalmente pelos proteoglicanos, glicoproteínas e água de solvatação.

Estes elementos conferem à matriz extracelular as suas propriedades biomecânicas. Deste modo, a viscosidade tecidual, a elasticidade e a capacidade de suportar forças compressivas (como a absorção de choque do impacto entre as pregas vocais durante a vibração) devem-se aos componentes da substância fundamental amorfa e à elastina presente nas fibras do sistema elástico. Por sua vez, o componente colágeno é responsável pela resistência às forças tênseis. 
O estudo da distribuição e a caracterização das proteínas fibrilares nas camadas da lâmina própria são importantes para se compreender a capacidade da prega vocal de manter a sua arquitetura sem restrição da movimentação livre da mucosa, mesmo quando submetida a variados tipos de forças, seja durante a sua vibração ou pela ação da musculatura intrínseca da laringe.

A maioria dos autores baseia-se na distribuição diferencial da substância fundamental amorfa e das fibras dos sistemas elástico e colagênico para identificar três diferentes estratos ou camadas na lâmina própria da prega vocal: superficial, intermediária e profunda.

As fibras colagênicas (colágenas e reticulares) têm sido exaustivamente estudadas na lâmina própria da prega vocal, através de métodos histológicos, bioquímicos, imuno-histoquímicos e ultra-estruturais, tendo se estabelecido que realmente estas se apresentem distribuídas diferencialmente na lâmina própria. Estudos mais recentes sugerem que na camada superficial, imediatamente abaixo do epitélio, existe uma trama de fibras colágenas densamente agregadas (colágeno I) distribuídas em todas as direções do espaço; logo abaixo, ocorre uma zona rica em delgadas fibras reticulares (colágeno tipo III) dispostas em forma de rede, e, mais profundamente, na região próxima ao músculo vocal, ocorre uma camada de fibras colagênicas densamente agregadas (colágeno tipo I).

A distribuição das diferentes fibras do sistema elástico começou a ser estudada recentemente sob a luz dos novos conhecimentos sobre as características tintoriais e ultra-estruturais de suas microfibrilas e da elastina. 
No entanto, o emprego de colorações antigas, da rotina histopatológica, como a hematoxilina férrica de Verhoeff, permite observar que, na lâmina própria da prega vocal do adulto, as fibras elásticas se concentram na sua região intermediária.

Ainda que a descrição da constituição específica e dos limites de cada uma destas camadas seja controversa na literatura, e mesmo que esteja baseada apenas em critérios morfológicos que carecem de correlação funcional, esta classificação tem sido a base para a definição de estruturas anatômicas e para as correlações fisiopatológicas. Um exemplo desta afirmação é o fato de que a estrutura denominada ligamento vocal corresponde à associação entre as camadas intermediária (rica em fibras elásticas) e profunda (rica em fibras colágenas).

Apesar da literatura extensa sobre a estrutura da lâmina própria das pregas vocais em adultos, existem poucos estudos sobre pregas vocais de fetos e crianças. A lâmina própria da prega vocal infantil é descrita como sendo constituída por grande quantidade de substância amorfa e esparsas fibras que não seguem um padrão de direção (SATO e HIRANO, 1995; CAMPOS BAÑALES et al., 1995; ISHII et al., 2000; SATO et al., 2001). Alguns trabalhos afirmam que o ligamento vocal é inexistente ao nascimento (SATO et al., 1995; ISHII et al., 2000; SATO et al., 2001; HARTNICK et al., 2005), permanecendo uma indefinição sobre qual exatamente a faixa etária na qual ocorre o surgimento do ligamento vocal estruturalmente semelhante ao do indivíduo adulto. 
No entanto, HAMMOND et al. (2000) foram explícitos ao descrever a existência de fibras colágenas distribuídas de forma compartimentalizada (como ocorre no adulto) na lâmina própria de prega vocal de crianças de 3 a 8 meses de idade, correspondendo a duas bandas de maior concentração: uma mais superficial, logo abaixo do epitélio, e outra, mais profunda, adjacente ao músculo vocal.

Desta forma, observamos que a informação sobre a estrutura histológica da corda vocal infantil, além de escassa é também contraditória.

Está bem demonstrado que mesmo após o nascimento, a prega vocal continua o seu processo de amadurecimento (HARTNICK et al., 2005). Uma revisão da literatura sobre a estrutura da lâmina própria das pregas vocais demonstra sua complexidade no estágio final do desenvolvimento. No entanto, pouco se sabe sobre a organização da lâmina própria da prega vocal ao nascimento. Acreditamos que este seja um ponto de interesse, uma vez que, é sobre esta base estrutural que ocorrerá o desenvolvimento a partir dos estímulos exógenos, no caso a fonação.

Além disso, do ponto de vista clínico, seria importante que organização estrutural da lâmina própria da prega vocal fosse bem descrita para que houvesse embasamento científico para tomada de condutas (cirúrgicas ou não) para o tratamento das lesões que acometam as pregas vocais na faixa etária infantil. 


\section{OBJETIVOS}




\section{OBJETIVOS}

Tendo em vista:

a) a escassez de trabalhos na literatura sobre a estrutura da prega vocal no período perinatal;

b) a controvérsia sobre a faixa etária na qual ocorre o aparecimento do ligamento vocal e a compartimentalização da lâmina própria da prega vocal humana, e

c) a importância do estudo da distribuição dos elementos fibrosos da matriz extracelular para a compreensão da biomecânica da vibração da prega vocal,

o objetivo deste estudo foi descrever, sob a luz dos atuais conhecimentos sobre a matriz extracelular, o padrão de distribuição das fibras dos sistemas colagênico e elástico na lâmina própria de pregas vocais de fetos humanos no último trimestre da gestação, através do emprego de métodos de identificação em microscopia de luz e microscopia eletrônica de transmissão. 


\section{REVISÃO DE LITERATURA}




\section{REVISÃO DE LITERATURA}

\subsection{Aspectos gerais sobre o tecido conjuntivo}

Os tecidos conjuntivos funcionam principalmente através de seus componentes extracelulares, no que diferem dos demais tecidos. De fato, o componente principal e mais abundante do tecido conjuntivo é a matriz extracelular. Os tecidos conjuntivos são estruturas biológicas complexas, formadas por uma variedade de componentes químicos distintos. Esses tecidos contêm células "nativas" (como fibroblastos, condrócitos, osteócitos), células relacionadas à atividade de patrulha imunológica (como polimorfomonucleares, macrófagos, mastócitos), vasos sangüíneos, nervos e toda a gama de componentes da matriz extracelular, como o colágeno (na sua fibrilar e não fibrilar), os proteoglicanos, as fibras do sistema elástico, glicoproteínas adesivas, além de água de solvatação e minerais. A quantidade relativa de cada um dos componentes varia significativamente em cada tecido conjuntivo em particular e também com a idade (PARRY e CRAIG, 1988).

Além de fornecer o suporte estrutural para os tecidos, a matriz se constitui em importante meio através do qual transitam informações entre as células, participando direta ou indiretamente de uma série de processos que incluem morfogênese, diferenciação e migração celulares. $O$ tecido conjuntivo também participa ativamente nos processos de reparo e fibrose, quando ocorrem interações dinâmicas e complexas entre os elementos matriciais. As diversas concentrações e associações dos componentes da 
matriz extracelular resultam em adaptações específicas às necessidades funcionais em cada órgão e cada componente participa na construção de uma matriz perfeitamente talhada para as necessidades individuais das células num determinado órgão, permitindo a manutenção da homeostase, a diferenciação em cada estágio do desenvolvimento e adaptações face a novos estímulos (MONTES, 1996).

\subsubsection{As fibras do sistema elástico}

O sistema elástico é composto por fibras elásticas, fibras elaunínicas e fibras oxitalânicas. As fibras elásticas são conhecidas dos anatomistas há mais de um século por suas propriedades tintoriais características, que se devem à presença da elastina (seu principal componente - ao redor de 90\%). Em 1958, FULLMER e LILLIE descreveram as fibras oxitalânicas e, em 1965, GAWLIK descreveu um outro tipo de fibra do tecido conjuntivo à qual denominou elaunínica.

Diversos indícios apontam para o fato de que os três tipos diferentes de fibras do sistema elástico pertençam a uma série contínua, sendo a ordem cronológica durante a histogênese a de fibras oxitalânicas, fibras elaunínicas e fibras elásticas. Observações das fibras do sistema elástico em vários animais, particularmente invertebrados, sugerem que as fibras oxitalânicas e elaunínicas são precursoras não só ontogenéticas, mas também filogenéticas das fibras elásticas propriamente ditas dos mamíferos (BRADAMANTE e SVAJGER, 1977; SAGE e GRAY, 1979).

Nos três tipos de fibras ocorrem feixes de microfibrilas (denominadas "microfibrilas da fibra elástica" por ROSS e BORNSTEIN, 1969) com 
quantidades crescentes de elastina associada, segundo a seqüência: oxitalânica, elaunínica e elástica. Outro ponto de interesse é que todas as observações ao microscópio eletrônico mostram que as microfibrilas constituintes das fibras oxitalânicas têm o mesmo diâmetro daquelas que circundam o cerne de elastina presente nas fibras elásticas maduras; e estudos imuno-histoquímicos também mostram pouca diferença entre elas (STREETEN e LICARI, 1983; GIBSON e CLEARY, 1987).

\subsubsection{Biossíntese e caracterização dos diferentes tipos de fibras} do sistema elástico

Ao se discutir tecidos elásticos, deve-se diferenciar os termos "elastina" e "fibras elásticas". A fibra elástica é a estrutura complexa encontrada na matriz extracelular, que contém elastina, proteínas microfibrilares, lisil-oxidase e proteoglicanos. A elastina é a proteína predominante de uma fibra elástica madura, sendo responsável por sua propriedade mecânica característica de recolhimento elástico. É uma proteína quimicamente inerte e extremamente hidrofóbica, cuja resistência à dissolução é tão grande que, antes da descoberta de seu precursor solúvel (a tropoelastina), só era possível definir a elastina em termos operacionais e qualitativos como o resíduo protéico insolúvel que restava após a solubilização de todos os componentes do tecido (PARTRIDGE, 1962). Além de suas propriedades físicas incomuns, a elastina é estável em condições fisiológicas permanecendo nos tecidos por todo o tempo de vida do organismo (LEFEVRE e RUCKER, 1980; SHAPIRO et al., 1991). 
Apesar dos avanços na compreensão da complexidade estrutural das microfibrilas, os mecanismos de sua efetiva participação na fibrilogênese permanecem especulativos. O fato de que agregados de microfibrilas assumem a forma e a orientação das supostas fibras elásticas levou ROSS et al. (1977) a sugerir que as microfibrilas direcionariam a morfogênese das fibras elásticas agindo como moldes para a deposição de elastina. Parece que as microfibrilas conseguem alinhar as moléculas de tropoelastina (que é a forma solúvel secretada pelas células) de uma maneira precisa, de modo a justapor os locais das ligações cruzadas nas moléculas, antes que eles possam ser oxidados pela lisil-oxidase (ROSENBLOOM et al., 1993).

Em certas regiões anatômicas específicas, encontram-se feixes de microfibrilas (atualmente conhecidos como fibras oxitalânicas), em tecidos que não contêm elastina, mesmo quando maduros. Em outras localizações, mesmo em animais adultos, todos os espécimes estudados sempre apresentam grumos de material amorfo entremeados aos feixes de microfibrilas (padrão que corresponde ao aspecto ultra-estrutural das fibras elaunínicas) e que nunca dão origem a fibras elásticas completamente maduras. Estas observações mostraram que nem todos os feixes de microfibrilas estão destinados a servir como molde para a deposição de elastina dando origem a fibras elásticas propriamente ditas.

Com base nestes achados, COTTA-PEREIRA et al. (1976) propuseram que as referidas fibras do sistema elástico (fibras oxitalânicas e fibras elaunínicas) representam interrupções em estágios sucessivos do desenvolvimento das fibras elásticas. Assim, um feixe de microfibrilas pode 
tanto ser o precursor de uma fibra do sistema elástico (tenha ela moderadas ou grandes quantidades de elastina) quanto permanecer como uma entidade independente, própria do tecido conjuntivo (as assim chamadas fibras oxitalânicas).

Esta foi a razão pela qual FULLMER (1960) propôs que fosse usado o termo fibras oxitalânicas para designar as fibras que jamais dão origem a fibras elásticas, mesmo em tecidos adultos, e que o termo fibras préelásticas fosse usado no caso de tecidos elásticos em desenvolvimento, para designar estruturas em processo de maturação.

\subsubsection{Distribuição diferencial e características funcionais das}

\section{fibras do sistema elástico}

As fibras do sistema elástico não se apresentam homogeneamente distribuídas nos tecidos, sendo que em compartimentos distintos dos vários órgãos seus componentes diferem tanto qualitativa quanto quantitativamente. Com o emprego de diversos métodos de investigação, foi demonstrada a existência de uma distribuição diferencial das fibras do sistema elástico em vários órgãos, a saber: pele (COTTA-PEREIRA et al., 1976; JUNQUEIRA et al., 1983), cartilagem hialina (COTTA-PEREIRA et al., 1984), mucosa das vias aéreas (BÖCK e STOCKINGER, 1984), nervos (FERREIRA et al., 1987) e tendões (CALDINI et al., 1990).

A existência de uma distribuição diferencial destas fibras nos tecidos é sugestiva de que o grau variável de elasticidade que cada uma das distintas fibras do sistema elástico apresenta, imprime versatilidade ao sistema. É a elastina quem confere elasticidade às fibras (ROSS e BORNSTEIN, 1969), 
assim, as fibras elásticas, que apresentam a maior quantidade de elastina, têm as propriedades elastoméricas mais evidentes, já as fibras oxitalânicas não se distendem sob tensão (ROSS, 1973) e atuam impedindo o estiramento das estruturas presentes nas regiões onde elas ocorrem, enquanto as fibras elaunínicas têm um grau intermediário de elasticidade (COTTA-PEREIRA et al., 1984).

Assim, as fibras elásticas propriamente ditas aparecem como um dos principais constituintes de tecidos conjuntivos que possuem propriedades elastoméricas, tais como o pulmão, os ligamentos elásticos e as paredes das artérias. As fibras oxitalânicas têm sido localizadas em regiões onde o tecido conjuntivo está sujeito a tensões mecânicas tais como: no periodonto humano (FULLMER e LILLIE, 1958), na junção dermo-epidérmica (COTTAPEREIRA et al., 1976), na zônula ciliar (STREETEN e LICARI, 1983), e também no endoneuro de todos os nervos estudados (FERREIRA et al., 1987), na membrana basal espessa da traquéia e da mucosa bronquiolar humanas (BÖCK e STOCKINGER, 1984), na matriz interterritorial da cartilagem hialina (COTTA-PEREIRA et al., 1984), nos filamentos de ancoragem dos capilares linfáticos (GERLI et al., 1990) e na lâmina própria dos túbulos seminíferos (BÖCK, 1978).

As fibras elaunínicas têm sido localizadas na interface entre a derme papilar e reticular (COTTA-PEREIRA et al., 1976), na região intermediária do "tendão elástico" do músculo eretor do pelo em humanos (RODRIGO et al., 1975), nos anéis paralelos que rodeiam a porção secretora das glândulas sudoríparas écrinas, na camada condrogênica do pericôndrio das cartilagens 
hialinas (COTTA-PEREIRA et al., 1984), no epineuro de todos os nervos estudados (FERREIRA et al., 1987), na camada sub-epitelial da traquéia e da mucosa bronquiolar em humanos (BÖCK e STOCKINGER, 1984) e na região intermediária do ligamento anular da articulação entre o estribo e a janela oval (SOUZA et al., 1991).

A presença de fibras oxitalânicas na zônula ciliar e no ligamento periodontal foi interpretada como uma evidência de que estes feixes de microfibrilas podem desempenhar um papel estrutural independente de sua função na elastogênese. As microfibrilas parecem ter uma função de ancoragem, ligando o cristalino ao corpo ciliar no olho, conectando o osso e o cemento do dente no ligamento periodontal e ligando a epiderme à derme subjacente, na pele. O componente microfibrilar pode ter uma função similar nas fibras elásticas, ancorando a elastina amorfa à matriz circundante (GIBSON e CLEARY, 1987).

A elastina se distribui sob a forma de fibras interligadas de três modos morfologicamente distintos: em ligamentos elásticos, nos pulmões e na pele, as fibras são pequenas alongadas e apresentam comprimento variável; na maioria das artérias, como a aorta, as fibras elásticas formam lâminas ou lamelas, já nas cartilagens elásticas se observa um arranjo tridimensional de fibras grandes, muito anastomosadas, em favo de mel (MECHAM e HEUSER, 1991). Essas estruturas complexas e distintas parecem surgir em conseqüência à intensidade e a direção das forças aplicadas ao tecido. 


\subsubsection{O sistema colagênico}

Os colágenos constituem uma família de proteínas fibrosas bem características, encontradas em todos os animais multicelulares, produzidas por diversos tipos de células, e que se distinguem em composição química, propriedades físicas, morfologia, distribuição nos tecidos e funções. São as proteínas mais abundantes nos mamíferos, constituindo cerca de $25 \%$ da sua massa protéica total.

A principal característica de uma molécula de colágeno típica, conhecida pelos histologistas como tropocolágeno, é a estrutura longa e rígida de sua fita tripla helicoidal na qual três cadeias polipepitídicas de colágeno, chamadas cadeias $\alpha$, estão enroladas umas nas outras (ALBERTS et al., 2002).

Existem vários tipos de cadeia $\alpha$ de colágeno e, portanto existem vários tipos de colágeno. Assim sendo, há os colágenos que formam fibrilas, os que formam fibras, os que se associam aos colágenos fibrilares e aqueles que formam estruturas em rede. Atualmente são conhecidos mais de 20 diferentes tipos de colágeno. Os colágenos que formam fibrilas são os tipos I, II, III, V, VI, VII e Xl; e suas estriações transversais típicas das fibrilas colágenas são conseqüências do arranjo das moléculas de tropocolágeno (ALBERTS et al., 2002). Tais estriações são facilmente identificadas nas micrografias eletrônicas. Aparecem como períodos de $64 \mathrm{~nm}$, cada período formado por duas faixas, uma clara e outra escura.

Os principais tipos de colágeno encontrados nos tecidos conjuntivos são os tipos I, II, III, IV, V e VII (ALBERTS et al., 2002). Os colágenos dos 
tipos I, II, e III são os principais constituintes de fibrilas e fibras intersticiais que contêm colágeno.

O tipo I, o mais comum, forma fibras grossas, conhecidas como fibras colágenas, presentes no tecido conjuntivo propriamente dito, no osso, dentina, cemento, tendão, fáscias, cápsulas dos órgãos, ligamentos, região profunda da derme; constitui cerca de $90 \%$ do colágeno do organismo. (MONTES, 1996). Caracteriza-se por formar fibras grossas, resistentes a tensão, formadas por fibrilas grossas densamente empacotadas, de diâmetro heterogêneo, com média de 50 a $60 \mathrm{~nm}$. Estas fibrilas se polimerizam e formam fibras de 2 a $10 \mu \mathrm{m}$ de diâmetro, correspondentes às clássicas fibras colágenas da microscopia de luz (que podem, ainda, se associar formando feixes de fibras) e aparecem principalmente em localizações sujeitas a grandes forças de tensão. Observadas sob microscopia de luz, as fibras colágenas são acidófilas, corando-se de róseo pela técnica da hematoxila-eosina, de azul pelo Tricrômio de Mallory e de verde pelo de Masson. As fibras colágenas são birrefringentes, pois são constituídas por moléculas alongadas e paralelas entre si. Desse modo, quando examinadas ao microscópio de polarização, entre filtros Polaroid cruzados, estas fibras aparecem brilhantes, contra um fundo escuro.

O colágeno do tipo II é encontrado em cartilagens elásticas e hialinas, no humor vítreo e no estroma da córnea de embriões. Suas fibrilas apresentam-se mais delgadas que as do colágeno do tipo I (medindo de 20 a $30 \mathrm{~nm}$ de diâmetro). Sua molécula é um homotrímero das cadeias alfa-1 e interage intensamente com os proteoglicanos da matriz extracelular. Esta 
interação é responsável, nas cartilagens, por sua resistência a forças compressivas.

O colágeno tipo III, geralmente co-distribuído com o colágeno tipo I, está presente em órgãos e tecidos que necessitam de um arcabouço estrutural maleável, como a região superficial da pele, a camada média dos vasos sanguíneos, a mucosa dos órgãos do trato digestório, respiratório e reprodutor e órgãos parenquimatosos como baço, fígado, medula óssea e pulmões. Durante os processos de reparo e nas fibroses em geral, assim como no desenvolvimento fetal, o colágeno III é o primeiro a ser depositado, sendo mais tarde substituído pelo colágeno do tipo I, nas regiões sujeitas a grandes forças de tensão. O colágeno do tipo III forma fibrilas de 35 a $55 \mathrm{~nm}$ de diâmetro, que são frouxamente empacotadas, com grande quantidade de substância amorfa entre si, formando fibras frouxas e flexíveis de 0,5 a $2 \mu \mathrm{m}$ de diâmetro, conhecidas como fibras reticulares, devido à sua característica de formar tramas de sustentação para células nos órgãos parenquimatosos. Nos preparados corados pela hematoxilina-eosina, as fibras reticulares não são visíveis, sendo sua identificação, em geral, realizada por meio de impregnações argênticas. Em virtude de sua afinidade pelos sais de prata, são chamadas também de fibras argirófilas do conjuntivo. Aparecem pretas nos processos de impregnação pela prata, enquanto as fibras colágenas tomam uma tonalidade castanha (MONTES, 1996).

O colágeno tipo IV não é um constituinte dos tecidos conjuntivos. Está presente nas lâminas basais. Suas moléculas se organizam formando uma espécie de malha frouxa e porosa, que interage com outras moléculas das 
lâminas basais, principalmente a laminina, a fibronectina e o heparam sulfato, porém não se polimeriza em fibrilas. É sintetizado pelas células epiteliais, células musculares e outras células que possuem lâmina basal.

O colágeno tipo VII é o principal componente das fibrilas de ancoragem, estruturas subepiteliais que promovem a interação biomecânica entre as fibrilas de colágeno do tecido conjuntivo com a membrana basal epitelial (WETZELS et al., 1991; DIKKERS et al., 1993; GRAY et al., 1995).

\subsection{Estrutura histológica da lâmina própria de pregas vocais de adultos}

HIRANO (1974) foi um dos pioneiros em descrever a estrutura histológica da prega vocal e correlacioná-la com a fisiologia da produção vocal. A partir da descrição da divisão da estrutura em epitélio, tecido conjuntivo e músculo vocal, introduziu a teoria de corpo-cobertura para a vibração das pregas vocais, segundo a qual a cobertura móvel, constituída pela membrana mucosa, pode vibrar sobre o corpo estacionário, constituído pelo músculo vocal e pela estrutura subjacente à qual denominou cone elástico.

As extremidades anterior e posterior da porção membranosa da prega vocal humana são denominadas, respectivamente, mácula flava anterior (ou nódulo elástico) e mácula flava posterior, entre as quais está disposto o ligamento vocal. A mácula flava anterior se insere no pericôndrio da cartilagem aritenóidea através do tendão da comissura anterior; a mácula flava posterior conecta-se ao processo vocal da cartilagem aritenóidea. Nos adultos, ambas as máculas são compostas por grande quantidade de fibras 
elásticas e de colágeno que se continuam com as do ligamento vocal (SATO e HIRANO, 1995a,b,c; SATO et al., 2003). As máculas flavas de pregas vocais infantis são ricas em fibroblastos que produzem muitas fibras da matriz extracelular; esta densidade celular diminui com a idade. Com estes achados, SATO e HIRANO (1995b,c) sugerem que as máculas flavas desempenham um papel importante na formação do ligamento vocal.

Na lâmina própria das pregas vocais adultas, inicialmente, foram descritas fibras colágenas grossas na região profunda da lâmina própria, formando feixes que correm paralelos à borda livre das pregas vocais (ISHII et al., 1996; MILUTNOVIC et al., 1998; GRAY, 2000). Posteriormente, foram descritas tramas de fibras finas, caracterizadas como fibras reticulares, nas camadas superficial e intermediária (SATO, 1998; SATO et al., 2002).

Recentemente, estudando a distribuição das fibras de colágeno através do método da Picrossírius-polarização, MELO et al. (2003) mostram a existência de duas bandas de fibras colágenas grossas densamente organizadas: uma logo abaixo do epitélio e outra na região profunda da lâmina própria; entre estas bandas localiza-se uma delicada rede de fibras colagênicas finas. Uma vez que o método permite estudar a agregação e a orientação destas fibras, os autores propõem um modelo no qual as bandas superficial e profunda seriam os elementos de transmissão de força, enquanto que a região central, por ser mais flexível, seria o elemento vibrátil do sistema. Devido às características de birrefringência mostradas pelo colágeno da prega vocal, os autores sugerem ainda que as fibras das 
bandas superficial e profunda seriam constituídas por colágeno do tipo I e as fibras finas da região central seriam compostas por colágeno tipo III.

Em relação à caracterização quanto ao tipo de colágeno presente na lâmina própria da prega vocal, alguns estudos imuno-histoquímicos estabelecem que colágenos dos tipos I e III encontram-se mais amplamente distribuídos, enquanto que os tipos IV e V se localizam na membrana basal dos epitélios de revestimento e glandulares e na lâmina basal endotelial (TATEYA et al., 2006). PAULSEN et al. (2000) descrevem a existência de colágeno tipos I e III nas máculas flavas e nas regiões de inserção do ligamento vocal. Fibrilas de colágeno tipo VII estão co-distribuídas com os outros tipos de colágeno na região mais superficial da lâmina própria e desempenham importante função de ancoragem entre os elementos da matriz extracelular e a lâmina basal epitelial (WETZELS et al., 1991; DIKKERS et al., 1993; GRAY et al., 1995;). TATEYA et al. (2006) estabelecem que as grossas fibras grossas localizadas na região superficial da lâmina própria são constituídas por colágeno tipo I, o que confirma a proposta de MELO et al. (2003).

Quanto à presença das fibras do sistema elástico na lâmina própria da prega vocal humana, alguns autores referem que as fibras do sistema elástico, de um modo geral, apresentam-se em menor quantidade na camada superficial, com aumento da concentração na camada intermediária e redução da concentração na camada profunda (HAMMOND et al., 1998, RAMOS et al., 2005). 
Os estudos em microscopia eletrônica de transmissão de ISHII et al. (1996), SATO e HIRANO (1997) e HAMMOND et al. (1997) mostram que na prega vocal estão representados os três tipos fibras do sistema elástico (elásticas propriamente ditas, elaunínicas e oxitalânicas), sendo que na região superficial predominam as fibras elaunínicas e oxitalânicas, enquanto que na zona intermediária predominam fibras elásticas propriamente ditas.

Já os estudos através de microscopia eletrônica de varredura são inconclusivos, devido à dificuldade de distinguir fibras de colágeno e fibras elásticas entre si. ISHII et al. (1996), utilizando técnicas de digestão para a retirada do colágeno da prega vocal e microscopia eletrônica de varredura, sugerem que há fibras elásticas distribuídas em toda a extensão da prega vocal, sendo mais finas na região superficial e mais grossas nas zonas intermediária e profunda, o que vai de encontro aos achados da microscopia eletrônica de transmissão (descritos anteriormente), uma vez que as fibras oxitalânicas são mais delgadas que as demais.

MILUTNOVIC et al. (1998), através de microscopia de luz e eletrônica de varredura, descreve a distribuição espacial das fibras e de outras estruturas em pregas vocais de adultos. Sugere que a disposição de diversas estruturas histológicas paralelamente à borda livre das pregas vocais demonstra um alto ajuste às necessidades fonatórias durante $\mathrm{o}$ processo de vibração das mesmas.

Além da descrição dos padrões de distribuição e dos tipos de fibras da matriz extracelular na lâmina própria das pregas vocais, estuda-se a sua influência sobre a biomecânica da vibração das mesmas. São encontradas 
diferenças nas características das curvas de tensão-deformação entre as regiões da lâmina própria, entre ambos os sexos e entre as faixas etárias, correlacionando-se com diferenças de quantidade e qualidade das fibras colagênicas e do sistema elástico (GRAY et al., 2000; CHAN et al., 2007).

\subsection{Estrutura histológica de pregas vocais de fetos, neonatos e crianças}

Em contraste com a estrutura histológica das pregas vocais humanas de adultos, sugere-se que durante o período fetal e ao nascimento ainda não ocorra uma compartimentalização da lâmina própria quanto à distribuição das fibras da matriz extracelular (SUBOTIC et al., 1984; CAMPOS BAÑALES et al., 1995; HIRANO et al., 1999; SATO et al., 2001; HARTNICK et al., 2005). Adicionalmente, relata-se que o ligamento vocal não está presente ao nascimento (SATO e HIRANO, 1995b; SATO et al., 2001; HARTNICK et al., 2005)

O papel das máculas flavas na organização da lâmina própria tem sido considerado muito importante, inclusive sugerindo-se sua participação como fonte de fibras da matriz extracelular para toda a estrutura (SUBOTIC et al., 1984; SATO et al., 1995; CAMPOS BAÑALES et al., 1995; HIRANO et al., 1999; SATO et al., 2001; SATO et al., 2003).

Alguns autores descrevem as características das fibras da matriz extracelular presentes na lâmina própria das pregas vocais imaturas. SUBOTIC et al. (1984) em estudo de laringes de fetos no segundo trimestre gestacional, utilizando cortes horizontais preparados com colorações 
hematoxilina-eosina, Van Gieson, combinação Mallory-Azan e Paraldeídofucsina para fibras elásticas, descrevem a presença de redes irregulares de fibras reticulares e fibras de aspecto ondulado dispostas paralelamente à borda livre e em toda a extensão da lâmina própria da prega vocal. Referem ainda que não são encontradas fibras elásticas. CAMPOS BAÑALES et al. (1995), em estudo no qual analisa cortes horizontais de pregas vocais de fetos no mesmo período gestacional, utilizando técnicas de coloração com hematoxila-eosina, Tricrômio de Masson e Van Gieson (para fibras colágenas), Gomory (para fibras reticulares) e orceína (para fibras elásticas), também descrevem a presença de fibras colágenas com as mesmas características, mas referem que em suas amostras não foram encontradas fibras reticulares. HARTNICK et al. (2005), descrevem a presença de esparsas fibras reticulares e elásticas entremeadas a uma população celular de grande densidade em toda a extensão da lâmina própria de pregas vocais de neonatos.

BUHLER et al. (2007) descrevem o arranjo do colágeno na lâmina própria de laringe de fetos, através de cortes coronais na porção média da região membranosa das pregas vocais. Com a utilização de colorações de hematoxilina-eosina, método da Picrossírius-polarização e imunohistoquímica, identificam fibras colágenas dispostas em arranjo de cesta de vime, distribuídas por toda a sua espessura. Seus estudos morfométricos não permitem a caracterização de uma distribuição diferencial do colágeno nas diferentes regiões da lâmina própria. 
No entanto, através do uso de medidas quantitativas relativas da distribuição do colágeno na lâmina própria de pregas vocais, HAMMOND et al. (2000) descrevem que já nos lactentes de 3 a 8 meses encontra-se um padrão de distribuição do colágeno semelhante ao do adulto, principalmente nas regiões mais superficiais, próximas ao epitélio de revestimento, e adjacentes ao músculo vocal.

ISHII et al. (2000), em estudo no qual emprega técnicas de digestão para a retirada do colágeno e das fibras elásticas em diferentes amostras de prega vocal, observa em microscopia eletrônica de varredura, a presença de duas regiões distintas na lâmina própria de pregas vocais de fetos e neonatos, uma esparsa. Sugere que esta estrutura bilaminar deva ser uma condição preparatória imatura, a qual será posteriormente modificada ou reabsorvida e substituída por uma estrutura mais desenvolvida consistindo no ligamento vocal e nas máculas flavas. 


\section{CASUÍSTICA E MÉTODOS}




\section{CASUÍSTICA E MÉTODOS}

\subsection{Aspectos éticos}

Esta pesquisa foi aprovada sob o protocolo de número 132/04, pela Comissão Análise de Projetos de Pesquisa - CAPPesq da Diretoria Clínica do Hospital das Clínicas e da Faculdade de Medicina da Universidade de São Paulo, em 25 de março de 2004.

\subsection{Casuística}

Para o presente estudo foram utilizadas 18 laringes humanas excisadas de cadáveres de fetos de sete a nove meses de desenvolvimento, coletadas dentro de 24 horas após o óbito, obtidas por autópsia do Serviço de Verificação de Óbitos da Capital, no período de novembro de 2005 a setembro de 2007.

Foram incluídas no estudo somente peças anatômicas sem alterações macroscópicas observáveis em região de arcabouço laríngeo ou na região das pregas vocais. Outros critérios de exclusão foram: laringes de fetos macerados e laringes de indivíduos com alterações congênitas de qualquer outro órgão. A causa do óbito não foi levada em consideração.

As características dos indivíduos estudados podem ser observadas na Tabela 1. 
Tabela 1 - Características dos indivíduos incluídos na casuística

\begin{tabular}{lccccc}
\hline Caso & Sexo & Idade gestacional (meses) & Altura $(\mathbf{c m})$ & Peso $(\mathbf{g})$ & Causa do óbito \\
\hline 1 & $\mathrm{~F}$ & 7 & 40 & 2020 & Indeterminada \\
2 & $\mathrm{M}$ & 7 & 35 & 1200 & Indeterminada \\
3 & $\mathrm{M}$ & 7 & 35 & 900 & Indeterminada \\
4 & $\mathrm{~F}$ & 7 & 35 & 1500 & Indeterminada \\
5 & $\mathrm{M}$ & 7 & 40 & 1600 & Indeterminada \\
6 & $\mathrm{M}$ & 8 & 45 & 2000 & Indeterminada \\
7 & $\mathrm{M}$ & 8 & 40 & 2400 & Indeterminada \\
8 & $\mathrm{~F}$ & 8 & 40 & 1600 & Indeterminada \\
9 & $\mathrm{M}$ & 8 & 45 & 2000 & Indeterminada \\
10 & $\mathrm{~F}$ & 8 & 45 & 2400 & Indeterminada \\
11 & $\mathrm{M}$ & 8 & 45 & 2200 & Indeterminada \\
12 & $\mathrm{~F}$ & 9 & 50 & 2950 & Indeterminada \\
13 & $\mathrm{M}$ & 9 & 50 & 2600 & Indeterminada \\
14 & $\mathrm{M}$ & 9 & 50 & 3500 & Indeterminada \\
15 & $\mathrm{~F}$ & 9 & 50 & 3400 & Indeterminada \\
16 & $\mathrm{M}$ & 9 & 50 & 2200 & Indeterminada \\
17 & $\mathrm{M}$ & 9 & 50 & 2800 & Indeterminada \\
18 & $\mathrm{~F}$ & 9 & 45 & 3100 & Indeterminada
\end{tabular}

Após dissecção das estruturas adjacentes, a laringe foi seccionada verticalmente em sua porção mediana, obtendo-se assim, duas hemilaringes para preparo histológico, como pode ser observado na figura 1. 

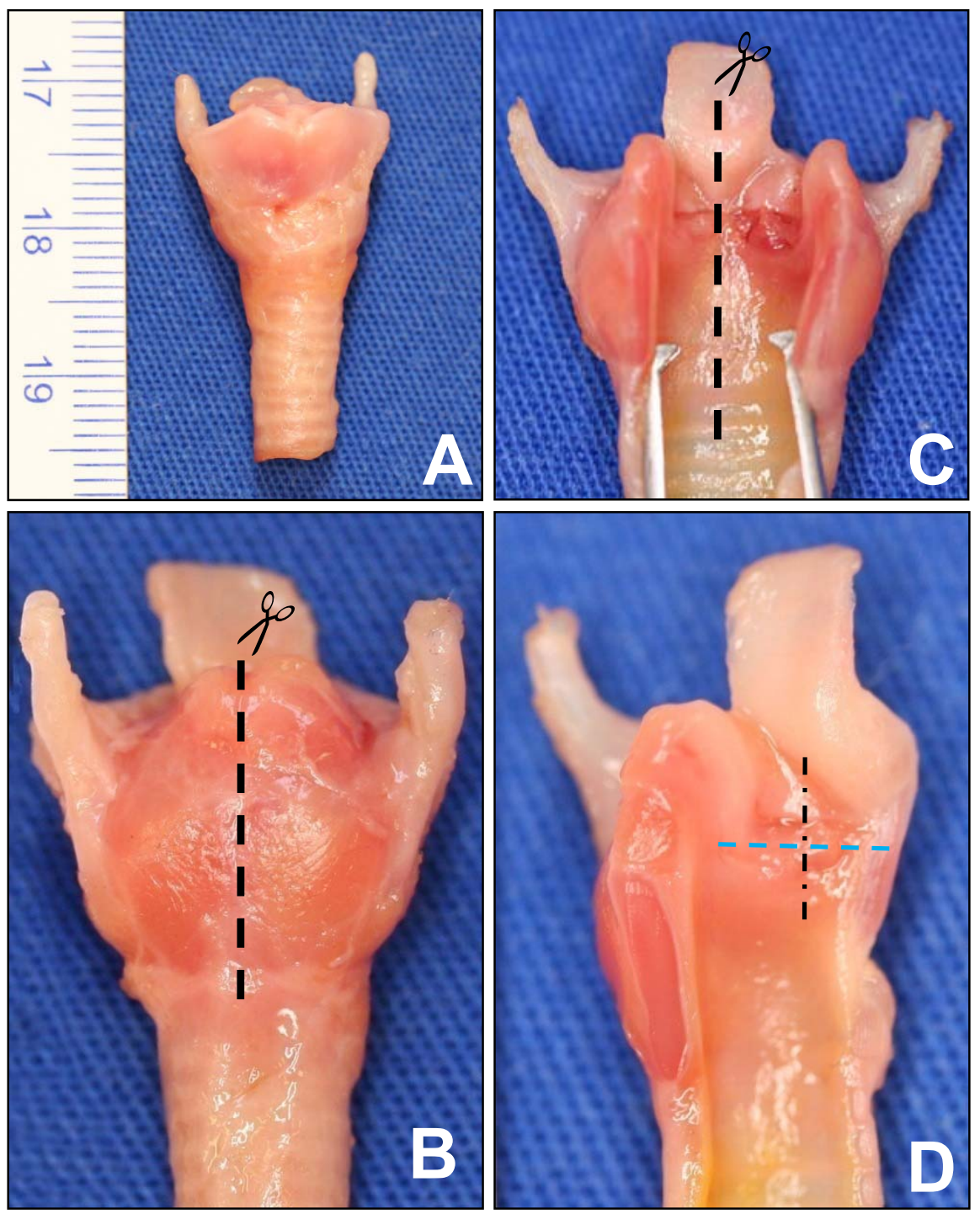

Figura 01 - Laringe de feto de 8 meses após a dissecção de estruturas adjacentes ilustrando o processamento para obtenção do material de estudo. A: visão frontal da laringe; B: visão posterior da laringe, ilustrando a linha de secção para exposição das pregas vocais. C: visão posterior da laringe após secção mostrando as pregas vocais e a comissura anterior; as hemilaringes foram separadas pela linha de secção marcada. D: aspecto de corte sagital mediano de hemilaringe esquerda mostrando os planos dos cortes histológicos obtidos para este estudo (plano horizontal marcado em azul e plano coronal marcado em preto). 


\subsection{Métodos para estudo em microscopia de luz}

Para estudo sob microscopia de luz, 28 hemilaringes (oito hemilaringes de fetos de sete meses, dez hemilaringes de fetos de oito meses e dez hemilaringes de fetos de nove meses) foram fixadas em paraformaldeído 4\% com tampão fosfato por 24 horas. Após a fixação, as peças foram dissecadas de modo a permanecer somente a estrutura da prega vocal, com o cuidado de se preservar as suas inserções anterior (na cartilagem tireóidea) e posterior (na cartilagem aritenóidea). Posteriormente, os fragmentos foram submetidos a desidratação em álcool e embebição em parafina para confecção dos blocos.

As pregas vocais direita e esquerda foram escolhidas aleatoriamente para cortes horizontais ou coronais. De cada fragmento escolhido foram obtidos cortes seriados de $5 \mu \mathrm{m}$ de espessura em diferentes profundidades do fragmento. Para comparação do conteúdo fibrilar na matriz extracelular, conjuntos de cortes histológicos adjacentes foram processados pelos seguintes métodos de identificação:

\subsubsection{Método da Hematoxilina-Eosina}

Os cortes histológicos foram corados pelo método de rotina da Hematoxilina e Eosina ( $\mathrm{HE})$, para avaliação histopatológica.

\subsubsection{Método da Picrossírius-polarização}

Os cortes histológicos foram desparafinados, hidratados e corados durante uma hora em uma solução 0,1\% de Sirius Red (Sirius Red F 3B 200, 
Mobay Chemical Co., Union, NJ, EUA) dissolvido em ácido pícrico aquoso saturado. Os cortes foram lavados durante cinco minutos em água corrente e contra-corados com hematoxilina de Harris fresca durante dois minutos. Foram observados sob microscopia de luz normal e sob luz polarizada contra um fundo escuro, para análise das fibras que contém colágeno.

\section{Princípio fundamental do método da Picrossírius-polarização:}

O corante Sirius Red é uma molécula alongada, de peso molecular 1372 Da, que possui seis grupamentos sulfônicos ácidos e quatro grupamentos cromofóricos diazóicos. Demonstrou-se que os grupamentos sulfônicos do corante interagem fortemente com os aminoácidos básicos das moléculas dos diferentes tipos de colágeno, sendo assim, muito apropriado para corar o colágeno em cortes histológicos (MONTES et al., 1985). Os quatro grupamentos cromofóricos conferem alto índice de extinção ao produto da interação, possibilitando a detecção, por meio de eletroforese em gel de poliacrilamida, de 5,76 $\mu \mathrm{g}$ de colágeno/mg de proteína (LOPEZ-DE LEON e ROJKIND, 1985).

A coloração pelo Picrossírius faz com que um grande número de moléculas do Sirius Red (de caráter ácido e alongadas) se oriente paralelamente ao longo do maior eixo das moléculas de colágeno, promovendo o aumento considerável da birrefringência natural das fibrilas e fibras de colágeno, quando observadas sob luz polarizada (JUNQUEIRA et al., 1979; MONTES, 1996). O aumento da birrefringência promovido pelo método da Picrossírius-polarização é portanto específico para as estruturas 
colágenas compostas por agregados de moléculas orientadas. Desse modo, quando examinadas ao microscópio de polarização, entre filtros Polaroid cruzados, estas fibras aparecem brilhantes, contra um fundo escuro.

\subsubsection{Método de Resorcina-Fucsina de Weigert com prévia} oxidação pela oxona

Esta é uma coloração para elastina, que demonstra fibras elásticas, elaunínicas e oxitalânicas conferindo-lhes uma cor púrpura. O procedimento foi realizado segundo MONTES (1996).

\section{Preparo do corante:}

Um grama de fucsina básica e dois gramas de resorcina foram adicionados a $100 \mathrm{~mL}$ de água destilada aquecida, fervidos até a dissolução completa. Após, foram adicionados $25 \mathrm{~mL}$ de uma solução de cloreto férrico $30 \%$ preparada recentemente. A fervura foi continuada por quatro minutos. Após resfriamento e filtragem da solução, o precipitado acumulado no papel de filtro foi secado em um forno elétrico a $56^{\circ}$. C. Em seguida, dissolveu-se o total de precipitado em $100 \mathrm{~mL}$ de etanol 95\% aquecido. Após resfriamento foi adicionado $1 \mathrm{~mL}$ de ácido hidroclorídrico concentrado $(\mathrm{HCl})$.

\section{Método:}

Os cortes histológicos foram desparafinados e levados até água, tratados com solução aquosa de Oxona a 10\% (composto monopersulfato, Du Pont, Wilmington, Delaware, EUA) por 40 minutos. Depois de lavados em água corrente por cinco minutos, foram lavados em uma série de etanol de concentrações de 70 a 95\%, e colocados na solução corante por uma hora 
em temperatura ambiente. Após este tempo na solução corante, foram lavados em água corrente por cinco minutos, a coloração de fundo foi removida por meio de uma solução de álcool etílico $1 \%(1 \mathrm{~mL}$ de $\mathrm{HCl}$ concentrado e $99 \mathrm{~mL}$ de etanol $70 \%$ ) por alguns segundos e os cortes observados ao microscópio de luz, com o cuidado de evitar a descoloração das fibras mais finas. Os cortes foram lavados em água corrente e desidratados em álcool, diafanizados e montados.

\subsection{Método para estudo em microscopia eletrônica de transmissão}

O material utilizado na obtenção dos cortes ultrafinos constituiu-se de pequenos fragmentos de tecido de diferentes regiões de prega vocal de quatro indivíduos (um feto de sete meses, um de oito meses e dois de nove meses), e foi processado seguindo rotina utilizada no Laboratório de Biologia Celular da Faculdade de Medicina da Universidade de São Paulo, resumida nas seguintes etapas: 1) Fixação por imersão em solução de glutaraldeído (Polaron, Watford, Inglaterra) 2,0\%, em tampão fosfato de sódio e potássio $0,15 \mathrm{M}, \mathrm{pH} 7,2$. A fixação deu-se durante 2 horas, à temperatura ambiente. 2) Lavagem em Solução de Lavagem $(\mathrm{NaCl} 6,0 \mathrm{~g}$, sacarose $73,0 \mathrm{~g}$, água destilada 1000 ml). 3) Pós-fixação numa solução de OsO4 (Tetróxido de ósmio anidro; Fisher, New York, EUA) a 1,0\%, em solução de lavagem, durante 1 hora, a $4^{\circ} \mathrm{C}$. 4) Rápida lavagem, seguida de pós-fixação por 18 horas em solução de acetato de uranila (Reidel e Haen, Hannover, Alemanha) 0,5\%, dissolvido na mesma solução de lavagem. 5) Desidratação em gradiente de etanol $(50 \%, 70 \%, 90 \%$ e 100\%) durante 1 hora. 6) Pré- 
embebição processada em misturas de etanol e resina (1:1, 1:2 e 1:3) durante 3 horas e embebição em resina pura durante 24 horas.

A resina utilizada para inclusão foi Araldite (Ladd Research Industries, Inc., Burlington, Vermont, EUA). Os fragmentos de tecido incluídos foram mantidos em estufa a $58^{\circ} \mathrm{C}$ durante 72 horas. Os blocos foram cortados em um ultramicrótomo LKB (modelo 8800 ultratome III), com a obtenção de cortes semifinos $(1 \mu \mathrm{m})$ que foram corados a quente (a aproximadamente $70^{\circ} \mathrm{C}$ ) em solução de Azul de Toluidina (Carbonato de Sódio 1,25g, Azul de Toluidina O (E.Merck, Alemanha) 0,50g e água destilada 50,00 ml).

Cortes ultrafinos, prateados, de aproximadamente $70 \mathrm{~nm}$ de espessura, foram obtidos no mesmo ultramicrótomo e contrastados por acetato de uranila a 2,0\%, durante 30 minutos, e por citrato de chumbo a $0,5 \%$, durante 10 minutos. O material foi estudado e micrografado em microscópio eletrônico Jeol, operado a 80 KV, no Centro Multiusuário de Microscopia Eletrônica do Laboratório de Biologia Celular do Hospital das Clínicas da Faculdade de Medicina da Universidade de São Paulo (LIM 59). 
RESULTADOS 


\section{RESULTADOS}

\subsection{Distribuição das fibras dos sistemas colagênico e elástico}

O material obtido por autópsia mostrou-se suficientemente íntegro para permitir o estudo histológico da lâmina própria das pregas vocais em todos os espécimes coletados.

Os achados foram os mesmos em todas as amostras, independentemente da idade fetal ou do sexo. Em secções horizontais de pregas vocais, observamos no nível glótico, com a coloração de HE, sua extensão completa desde a cartilagem tireóidea até a inserção na cartilagem aritenóidea. Observamos a estrutura em camadas classicamente descrita na literatura, constituída por epitélio, lâmina própria e músculo vocal. Nos fetos, a coloração pela HE revelou uma lâmina própria constituída por tecido conjuntivo frouxo entre o processo vocal da cartilagem aritenóidea e a cartilagem tireóidea, com a qual está conectada através do tendão da comissura anterior. A presença das máculas flavas anterior e posterior, classicamente descritas na literatura também foram confirmadas. Nos cortes submetidos a esta coloração não foi possível distinguir nenhuma estrutura com aspecto de ligamento ou compartimentalização em camadas na lâmina própria (Figuras 2 e 3).

Os cortes histológicos de prega vocal fetal corados com Picrossírius e observados com luz convencional permitiram evidenciar uma grande quantidade de fibras de colágeno na lâmina própria. Quando estes cortes foram estudados em microscopia de polarização, estas fibras mostraram-se 
como estruturas birrefringentes brilhando contra um fundo escuro com distribuição heterogênea na lâmina própria: na região mais superficial da lâmina própria e imediatamente superficial ao músculo observou-se maior birrefringência (sugerindo áreas de maior concentração de fibras de colágeno), enquanto que, na região central, observou-se uma fraca birrefringência, sugerindo pequena concentração de estruturas colagênicas (Figuras 4 a 5). Esta distribuição diferencial do colágeno permitiu caracterizar uma compartimentalização da lâmina própria da prega vocal fetal.

Quanto à inserção da prega vocal na cartilagem tireóidea, o método da Picrossírius-polarização permitiu observar que as duas regiões ricas em colágeno na lâmina própria são contínuas com tendão da comissura anterior e separadas entre si pela ocorrência da mácula flava anterior (Figura 6).

Os cortes teciduais corados pelo método de resorcina-fucsina de Weigert após oxidação permitiram observar a distribuição diferencial das fibras do sistema elástico na lâmina própria da prega vocal. Na região central intermacular, notou-se um acúmulo de fibras do sistema elástico organizadas paralelamente ao maior eixo da prega vocal. Além disso, observou-se a presença de uma lâmina de fibras elásticas, também paralelas entre si região, imediatamente na zona sub-epitelial (Figuras 7, 8 e $9)$.

Assim como as fibras colagênicas, as fibras do sistema elástico presentes na lâmina própria da prega vocal também se continuaram com as estruturas localizadas anterior e posteriormente. Na região anterior, esta 
continuidade se deu em toda a região da mácula flava (Figura 10), com inserção no tendão da comissura anterior, enquanto que na região posterior as fibras se inseriram na cartilagem elástica do processo vocal (Figura 11).

Os achados da microscopia eletrônica confirmaram as observações feitas na microscopia de luz. Na região superficial da lâmina própria, a microscopia eletrônica revelou a presença de fibras de colágeno formadas por fibrilas densamente empacotadas, entremeadas por alguns perfis de fibras do sistema elástico (Figura 12). Na região central da lâmina própria, as fibras do sistema elástico predominaram nas imagens, ao lado de finas fibras de colágeno (Figura 13).

O estudo detalhado, ao nível ultra-estrutural, permitiu observar que os três tipos de fibras do sistema elástico (elásticas propriamente ditas, elaunínicas e oxitalânicas) estavam presentes na lâmina própria da prega vocal fetal (Figuras 14 e 15).

\subsection{Aspecto ondulado das fibras de colágeno}

Em todos os espécimes estudados, o método da Picrossíriuspolarização mostrou grande quantidade de fibras de colágeno de aspecto ondulado distribuídas pela lâmina própria da prega vocal (Figura 16). A microscopia eletrônica confirmou estes achados, revelando a co-localização das fibras colágenas onduladas e das fibras do sistema elástico (Figura 17). Supõe-se que esta configuração permite o alongamento da fibra de colágeno mesmo com pequenas forças de tensão até o ponto em que as ondulações 
desapareceriam. O retorno ao padrão ondulado inicial ocorreria pela ação das fibras elásticas que se recolhem quando cessam as forças de tensão.

\subsection{Interação entre as células e as fibras da matriz extracelular}

As microfibrilas que compõem as fibras do sistema elástico apareceram em muitas localizações interagindo com a superfície celular, com as fibrilas de colágeno e com a lâmina basal do epitélio de revestimento (Figuras 18, 19 e 20, respectivamente), reforçando a idéia de que funcionam como fibras de ancoragem da matriz extracelular. Na região da lâmina basal foi possível observar também a presença de fibrilas de colágeno tipo VII, que ancoram proteínas da lâmina basal às finas fibrilas de colágeno subjacentes (Figura 21). 
Figura 2 - Corte histológico horizontal de prega vocal direita de feto de 8 meses, corado com HE. A prega vocal pode ser visualizada em toda sua extensão ânteroposterior, desde a cartilagem tireóidea (CT) até o processo vocal (PV) da cartilagem aritenóidea (CA) e em toda sua extensão latero-medial, desde o músculo vocal (MV) até o epitélio de revestimento (seta preta). Conectando a prega vocal à cartilagem tireóidea, observa-se o tendão da comissura anterior (TCA).

A lâmina própria (LP) compreende a região de tecido conjuntivo localizada entre o epitélio de revestimento e o músculo vocal. Através desta coloração este tecido conjuntivo pode ser classificado pelos critérios da Histologia Clássica, como tecido conjuntvo frouxo, que se caracteriza pela escassez de fibras da matriz extracelular e maior densidade de células.

As máculas flavas aparecem como duas regiões de maior concentração celular nas extremidades anterior (mácula flava anterior, MFA) e posterior (mácula flava posterior, MFP) da prega vocal.

Figura 3 - A imagem corresponde a um aumento maior de um corte histológico equivalente ao mostrado na Figura 2, evidenciando parte da mácula flava anterior (MFA). As células das máculas mostram-se densamente agrupadas com núcleos arrendondados, enquanto que o restante da lâmina própria as células estão distribuídas esparsamente e apresentam núcleos fusiformes. A matriz extracelular da lâmina própria, observada neste maior aumento, apresenta delgadas fibras esparsas (evidentes na região marcada com asterisco). Estas fibras estão coradas em róseo pela eosina e podem ser caracterizadas como fibras colágenas. Notar que não é possível identificar nenhuma compartimentalização da lâmina própria que fosse definida pela distribuição diferencial dos seus elementos. 

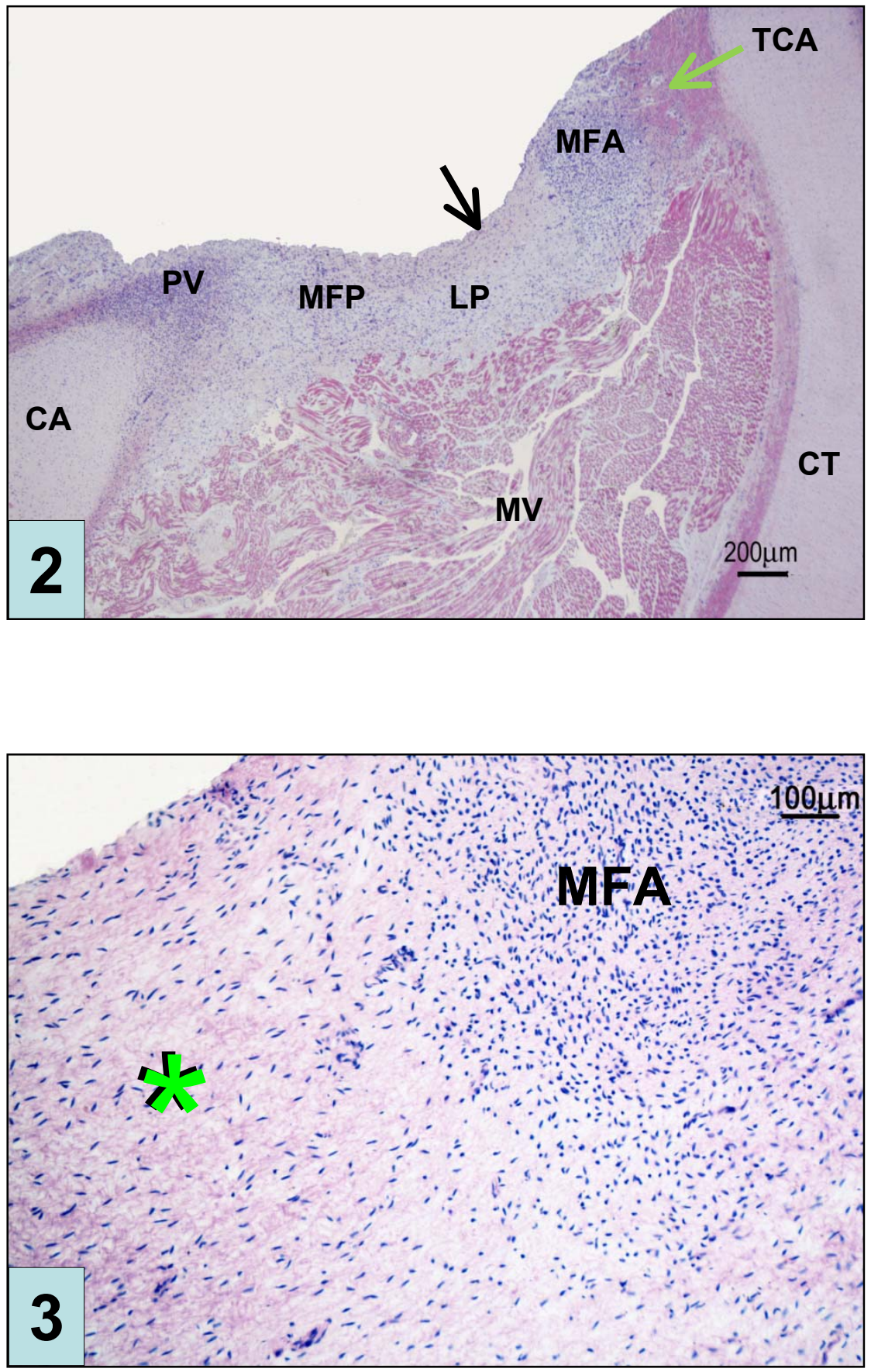
Figura 4 - Corte histológico corado com Picrossírius, contracorado pela Hematoxilina, e observado com luz convencional. Notar que este corte é adjacente àquele mostrado na Figura 2. O Picrossírius cora o colágeno fibrilar em vermelho profundo, que aparece destacado na lâmina própria. Comparar a melhor definição do colágeno com esta técnica em relação à coloração pelo $\mathrm{HE}$, mostrada na Figura 2. Deste modo, é possível identificar na lâmina própria (LP) duas regiões com maior concentração de fibras de colágeno: uma mais próxima ao epitélio de revestimento e outra adjacente ao músculo vocal (MV). Estas regiões estão marcadas com asteriscos.

Figura 5 - Quando o mesmo corte corado pelo Picrossírius é observado em microscopia de polarização, a birrefringência normal do colágeno aparece intensificada e as estruturas que contém colágeno mostram-se como estruturas birrefringentes brilhando contra um fundo escuro. O aumento de birrefingência nos cortes corados pelo Picrossírius estudados sob luz polarizada se mostra específica para o colágeno. Reparar que as mesmas regiões da lâmina própria, também apontadas com asteriscos na Figura 4 como ricas em colágeno, mostram-se com intensa birrefringência. Notar que estas faixas de fibras colagênicas se continuam, por um lado, com o pericôndrio da cartilagem aritenóidea (CA) e, pelo outro lado, com o tendão da comissura anterior (TCA). A região central da lâmina própria (assinalada com uma barra) mostra apenas algumas fibras de colágeno fracamente birrefringentes. 

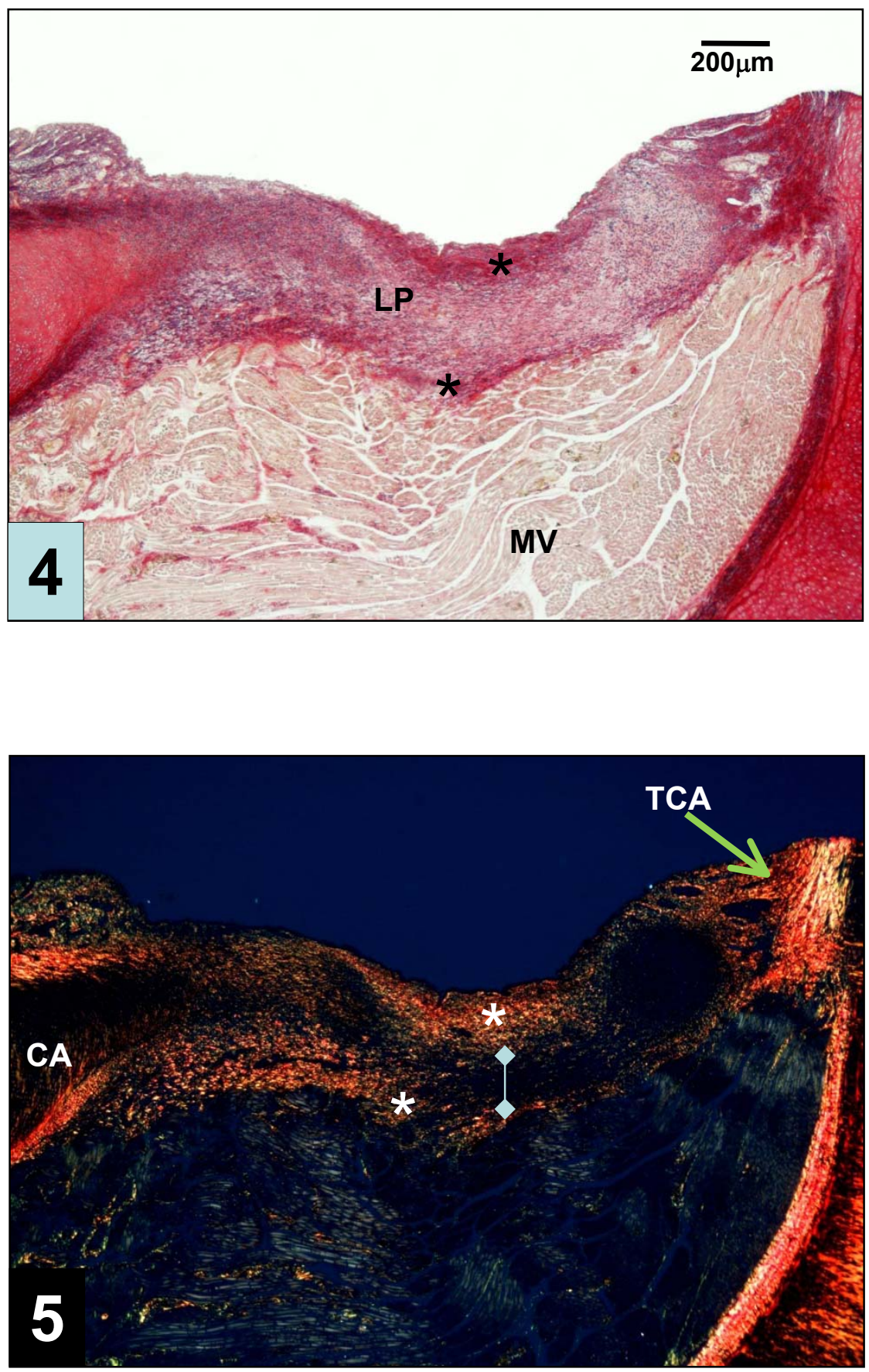
Figura 6 -. Imagem mostrando do mesmo corte histológico mostrado na Figura 5, em aumento maior. A região central da figura é ocupada pela mácula flava anterior (MFA). Observar que as faixas de maior concentração de colágeno (asteriscos) contornam a mácula flava anterior e se inserem no tendão da comissura anterior (TCA). Notar a riqueza de fibras colágenas do tendão, que aparecem como uma compacta massa de fibras colágenas grossas, orientadas paralelamente entre si, desde a mácula flava anterior até o pericôndrio da cartilagem tireóidea (CT). A barra assinala a região do ligamento vocal como definida na literatura; com esta técnica é possível evidenciar a porção colagênica do ligamento vocal já desenvolvida na camada profunda da lâmina própria.

Figura 7 - Corte histológico horizontal de prega vocal de 8 meses, corado com Resorcina-fucsina com oxidação prévia. Com esta coloração é possível evidenciar simultaneamente todos os tipos de fibras do sistema elástico. Notar que esta micrografia corresponde a um maior aumento se comparado ao da Figura 6. Aqui vêse somente a região intermacular da prega vocal. A barra assinala a região do ligamento vocal como definida na literatura; com esta técnica é possível evidenciar a porção elástica do ligamento vocal já desenvolvida na camada intermediária da lâmina própria, localizada entre os dois estratos ricos em colágeno (asteriscos, ver Figuras 5 e 6). Reparar que na região sub-epitelial é possível observar a presença de uma delgada zona rica em fibras do sistema elástico (seta vermelha); MV: músculo vocal. 

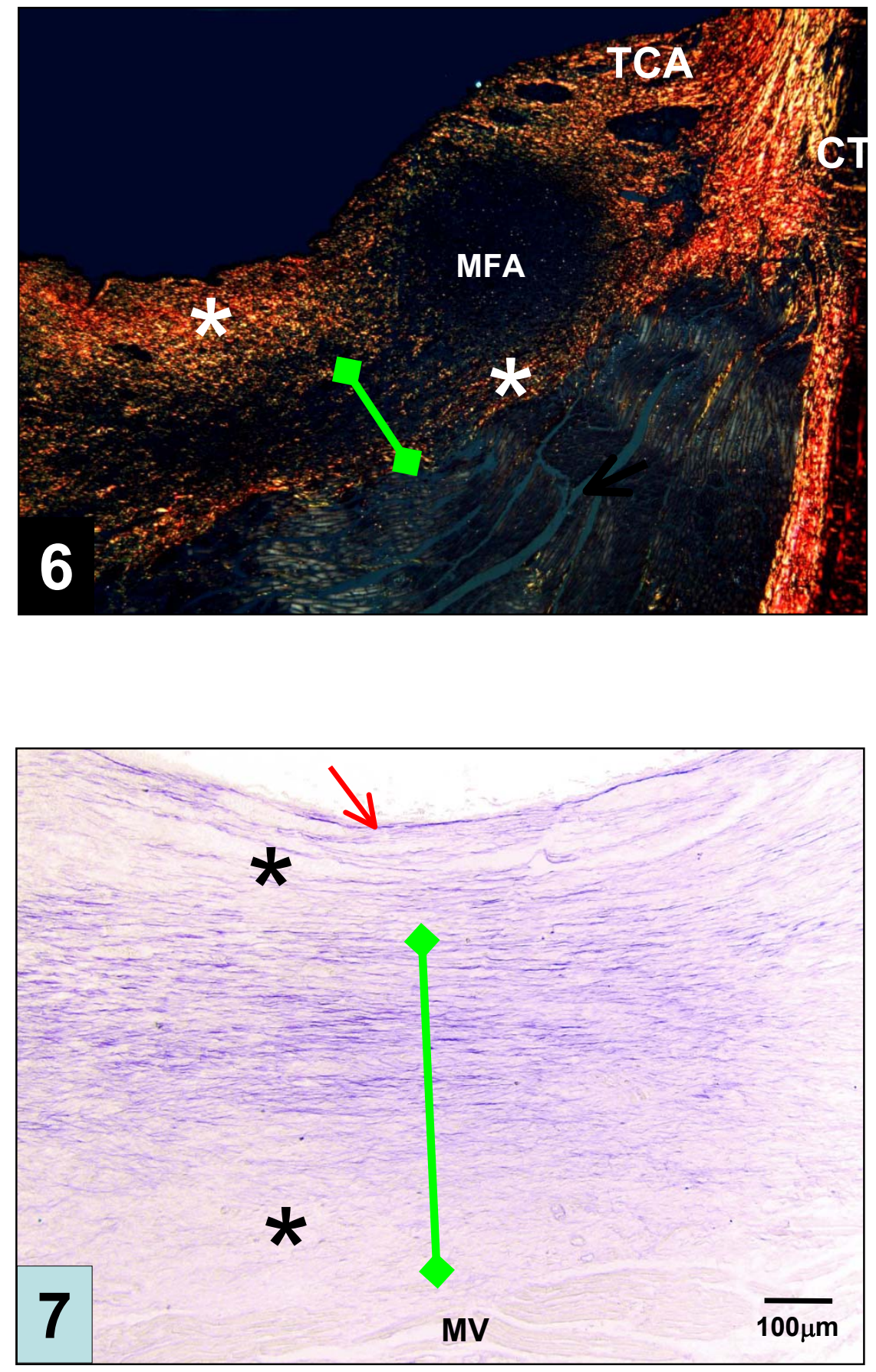
Figura 8 - Corte coronal de região intermacular de prega vocal esquerda de feto de 7 meses, corado com Resorcina-fucsna com oxidação prévia. A distribuição das fibras do sistema elástico pode ser facilmente evidenciada nesta micorgrafia de maior aumento. Uma vez que estas fibras se organizam paralelamente ao maior eixo da prega vocal, é possível observá-las cortadas transversalmente nos cortes coronais.

A letra E marca o epitélio de revestimento. Reparar as fibras do sistema elástico alinhadas na região sub-epitelial (seta vermelha). O restante da figura corresponde à região da lâmina superficial da lâmina própria (asterisco), que possui esparsas fibras do sistema elástico. Esta é uma região dominada por grande quantidade de fibras colagênicas, como demonstrado nas Figuras 4, 5 e 6.

Figura 9 -Micrografia do mesmo corte da Figura anterior, obtida da região central da lâmina própria. É possível observar uma grande quantidade de perfis transversais de fibras do sistema elástico, que preenchem esta região pobre em fibras colagênicas, como demostrado nas Figuras 4, 5 e 6. 

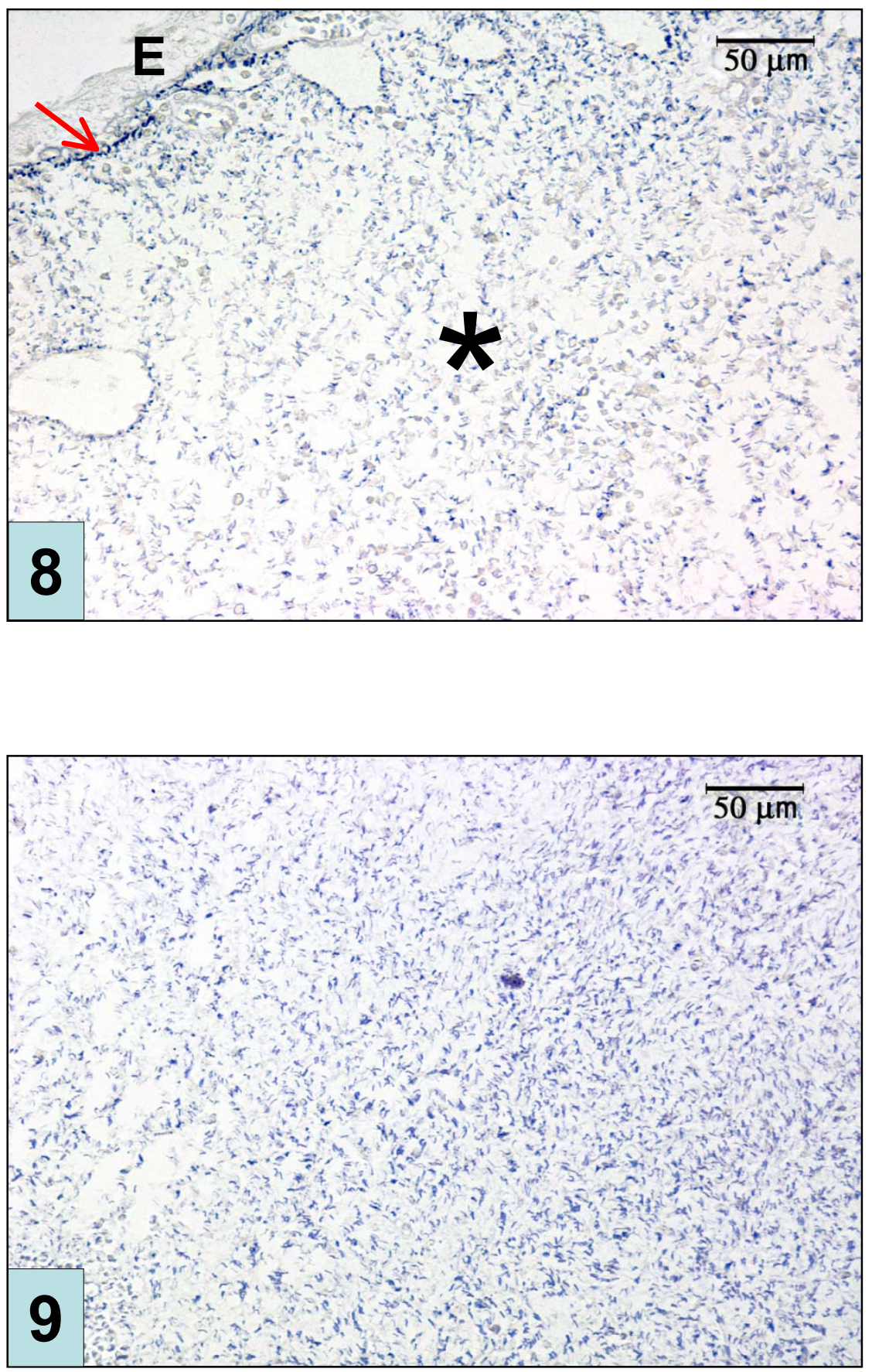
Figura 10 - Micrografia de corte horizontal da prega vocal de feto de 9 meses de idade, corado com Resorcina-fucsina, após oxidação. Notar que as fibras do sistema elástico (seta) se dispõem ao longo do maior eixo da prega vocal e se continuam com aquelas da mácula flava anterior (MFA). Esta região é especialmente rica em fibras do sistema elástico. Notar que estas fibras são mais escassas no tendão da comissura anterior (TCA).

Figura 11 - Micrografia obtida do mesmo corte histológico da figura anterior, mostrando a região posterior da prega vocal. Notar na extremidade da cartilagem aritenóidea a presença do processo vocal (PV), que se caracteriza pela grande quantidade de fibras elásticas, correspondendo à descrição de cartilagem elástica pela Histologia Clássica. Nesta localização, as fibras do sistema elástico se continuam com àquelas presentes na mácula flava posterior (MFP), que por sua vez, se continuam com as fibras presentes na região central da lâmina própria. Reparar que a mácula flava posterior contém menor quantidade de fibras do sistema elástico que a mácula flava anterior (ver figura 10). 

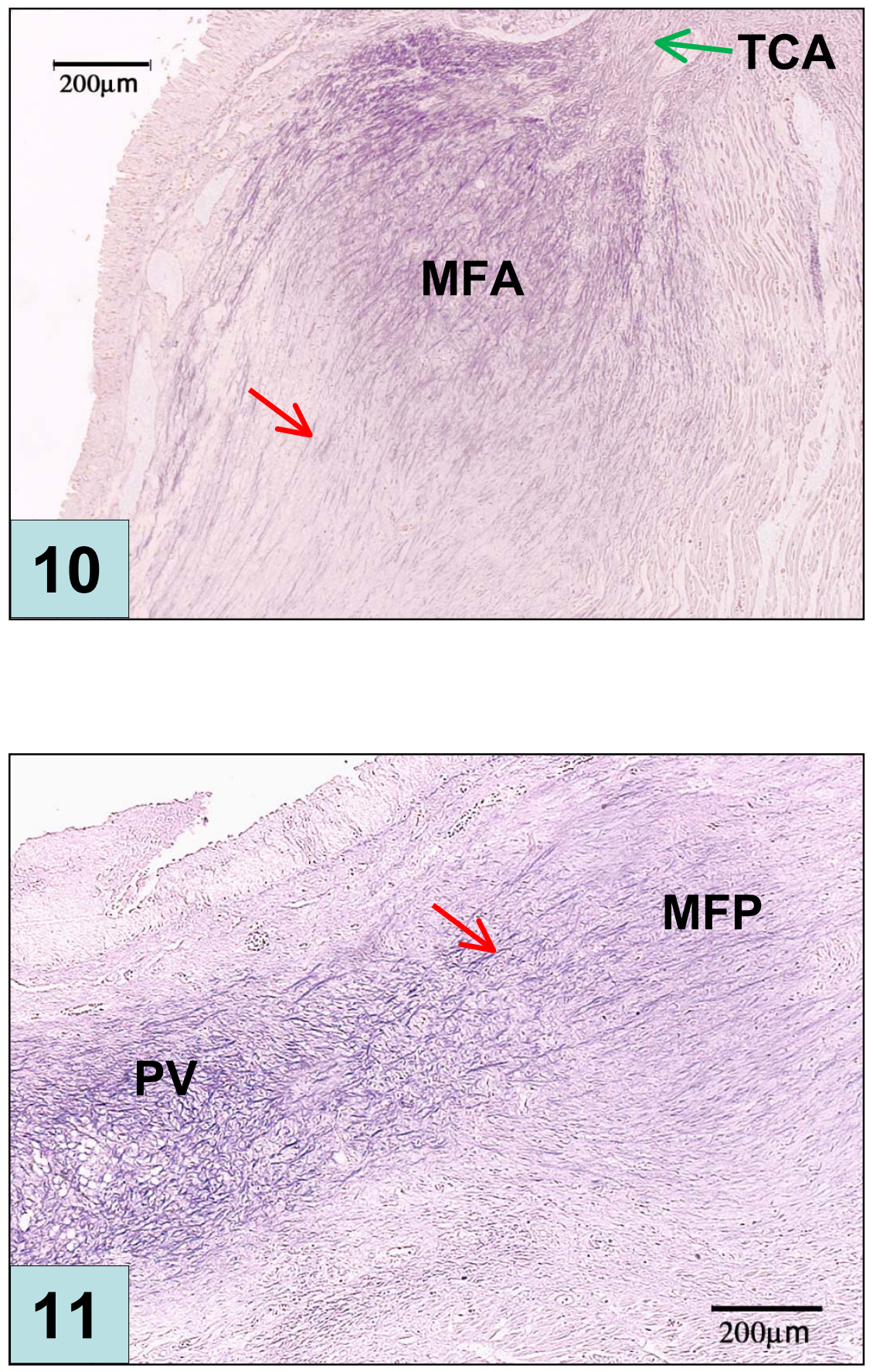
Figura 12 - Micrografia eletrônica da região superficial da lâmina própria de prega vocal de feto de 9 meses. A Figura mostra parte do citoplasma de dois fibroblastos (F) rodeados pela matriz extracelular. As fibras de colágeno (C) aparecem constituídas por suas fibrilas (a maioria delas cortadas transversalmente). Reparar que as fibras do sistema elástico (setas) mostram-se como delgadas fibras de perfil compacto imiscuídas por entre as fibras de colágeno.

Figura 13 - Micrografia eletrônica de outro fragmento da mesma prega vocal mostrada na figura anterior. Esta imagem é representativa do aspecto observado na região central da lâmina própria de todos os espécimes estudados. Nesta região também são encontrados fibrblastos $(\mathbf{F})$ como o principal tipo celular presente. $O$ componente colágeno (C) aparece sob a forma de fibras formadas por fibrilas finas dispostas em várias direções do espaço (aparecem em perfis longitudinais e transversais). Observam-se grossas fibras do sistema elástico (E), cortadas transversalmente, que pela compactação do seu cerne amorfo de elastina, podem ser classificadas como fibras elásticas propriamente ditas (maduras). 

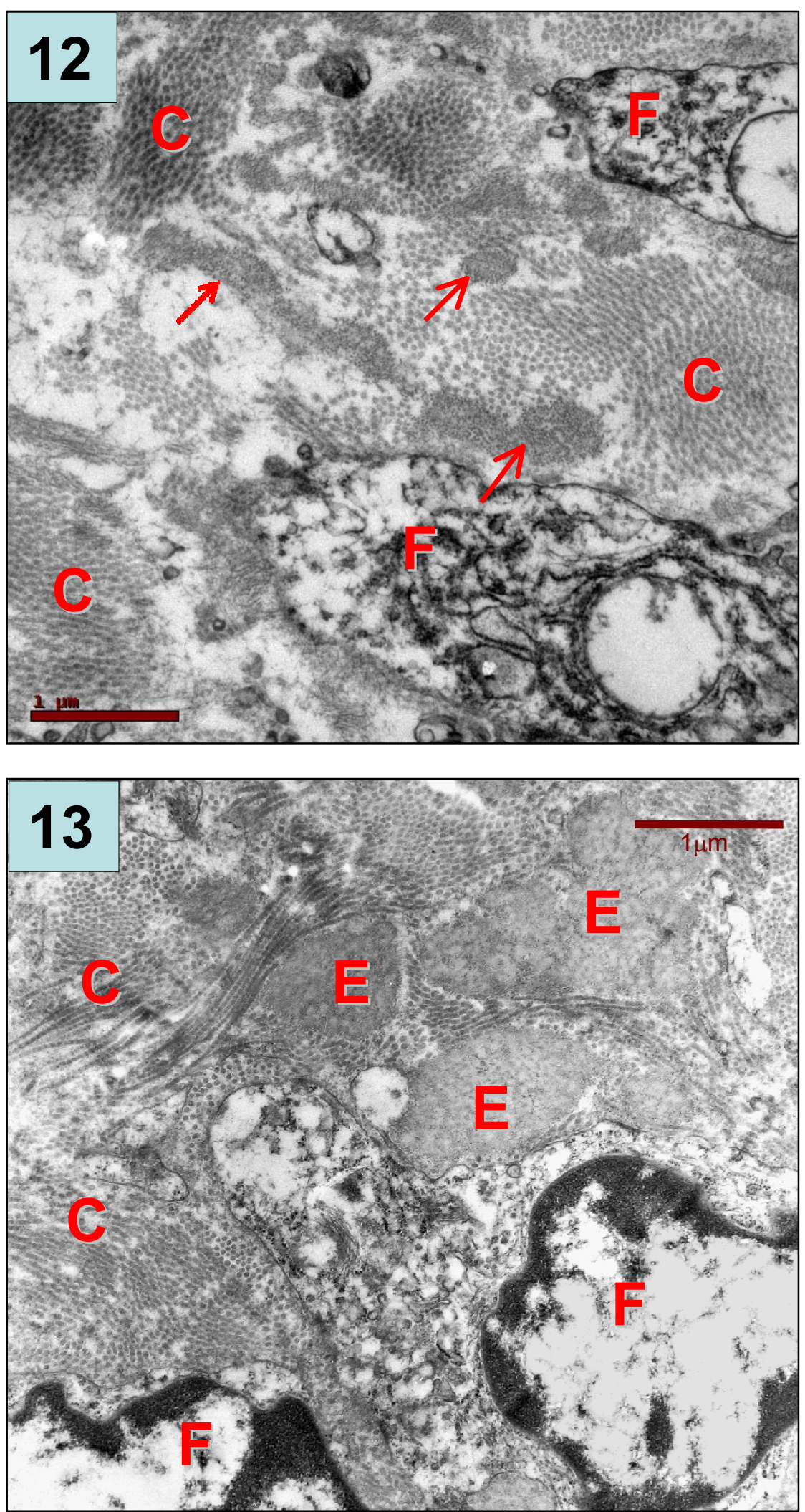
Figura 14 - Micrografia eletrônica de grande aumento mostrando parte de um fibroblasto $(\mathbf{F})$ e componentes da matriz extracelular ao seu redor, principalmente fibrilas de colágeno (C) e parte de uma fibra elástica propriamente dita (E). Essa apresenta-se constituída por grande quantidade de material amorfa (elastina) e alguns componentes microfibrilares ao seu redor. Notar a interação existente entre estas microfibrilas da fibra elástica e a membrana celular (seta).

Figura 15 - Micrografia eletrônica de um fragmento de lâmina própria da prega vocal fetal. A matriz extracelular presente entre as duas porções celulares (fibroblastos, F) apresenta fibrilas de colágeno cortadas transversalmente $(\mathbf{C})$ e diferentes perfis de elementos do sistema elástico. Na periferia do fibroblasto da região superior esquerda da figura aparecem fibras oxitalânicas $(\mathbf{O x})$, constituídas apenas por microfibrilas, enquanto que na periferia do fibroblasto embaixo à direita, observa-se uma fibra elaunínica (Eln), composta por microfibrilas e acúmulos esparsos de elastina amorfa. 


Figura 16 - Corte histológico horizontal de prega vocal humana de feto de 8 meses, corado com Picrossírius-hematoxilina, observado em luz convencional. As setas apontam algumas das fibras de colágeno presentes na lâmina própria que exibem perfil ondulado (crimp). Esta configuração é típica de estruturas como tendões e ligamentos.

Figura 17 - Micrografia eletrônica de prega vocal de feto de 8 meses. Observar a presença de uma fibra de colágeno com aspecto ondulado. Este padrão é facilmente diagnosticado em microscopia eletrônica uma vez que uma mesma fibra apresenta regiões em corte transversal (à direita da letra $\mathbf{C}$ ) e outras em corte longitudinal (à esquerda da letra $\mathbf{C}$ ). Observar que a presença de uma fbra elástica propriamente dita adjacente à fibra de colágeno e a um fibroblasto $(\mathbf{F})$. 

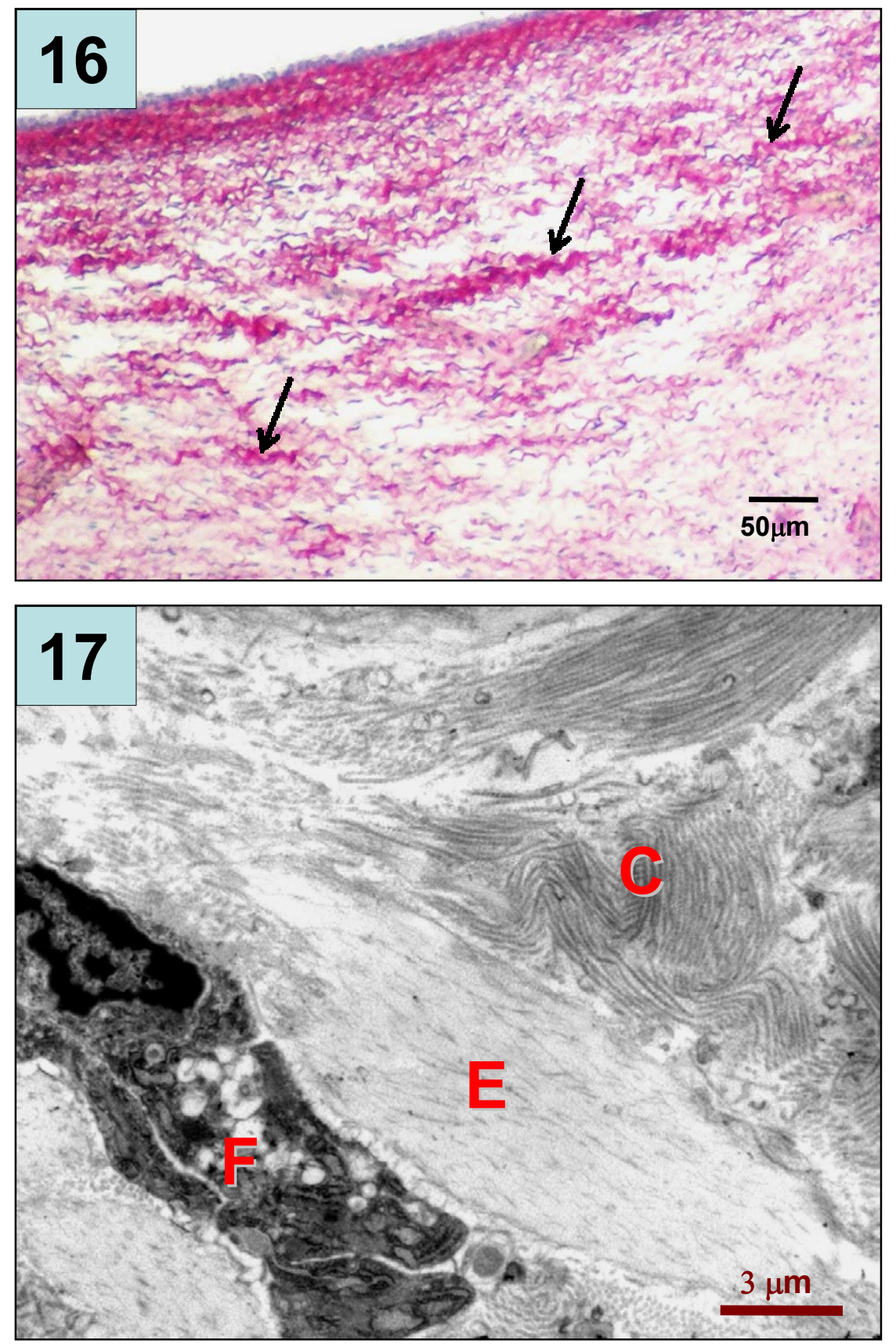
Figura 18 - Micrografia eletrônica de gradíssimo aumento obtida de prega vocal de feto de 9 meses, mostrando um prolongamento celular revestido externamente por microfibrilas do sistema elástico (seta). Estas são inestensíveis e conferem resistência mecânicas às estruturas nas quais se inserem.

Figura 19 - Micrografia eletrônica de grande aumento obtida de prega vocal de feto de 8 meses, mostrando um conjunto de fibras elaunínicas (Eln) e várias fibrilas de colágeno cortadas transversalmente (C). No centro da figura é possível observar que as microfibrilas de uma das fibras elaunínicas interagem diretamente com uma fibrila de colágeno (que aparece cortada longitudinalmente, seta). 

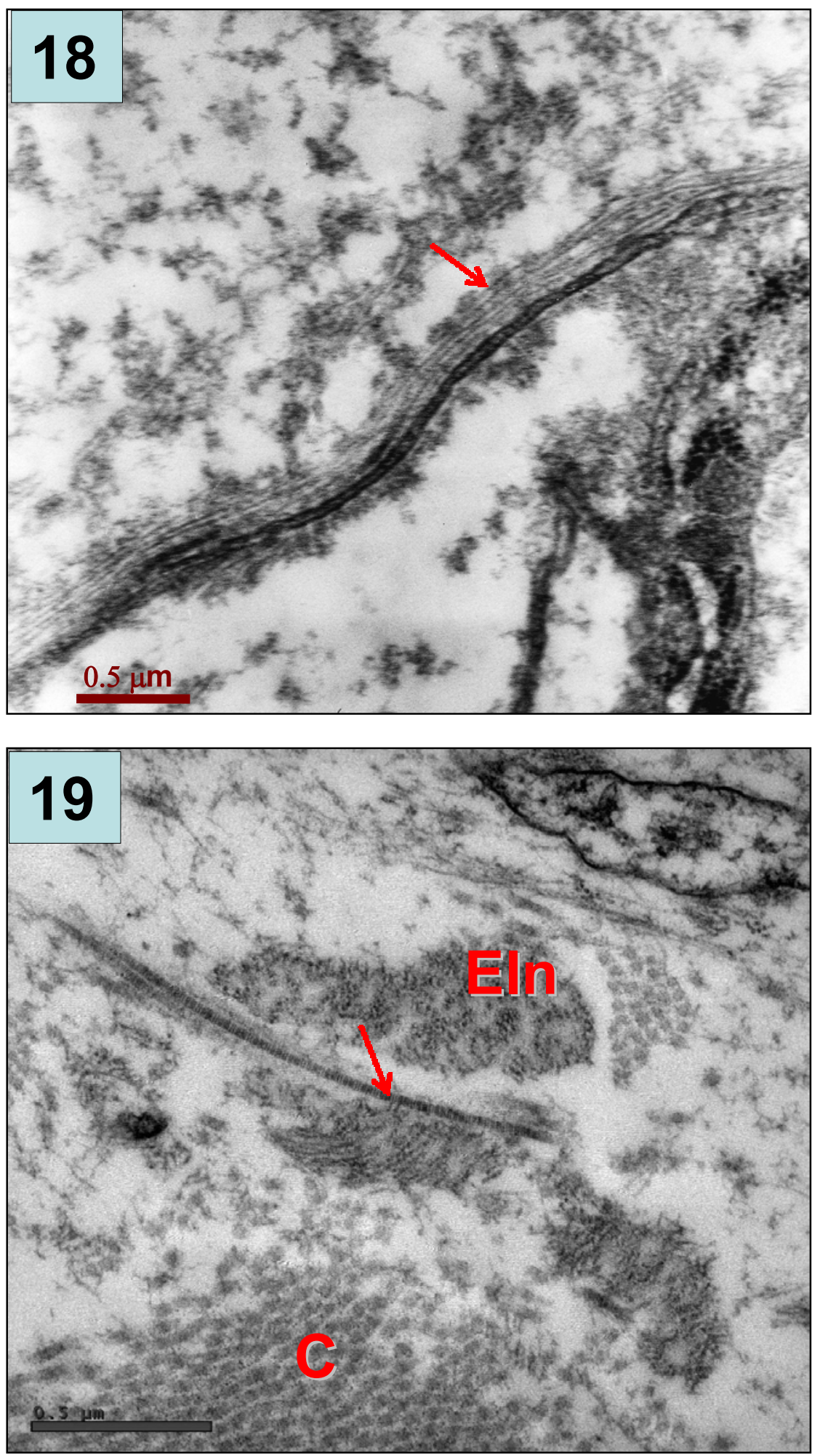
Figura 20 - Micrografia eletrônica de prega vocal obtida de feto de 9 meses. Na região superior da imagem é possível observar a partes da porção basal de duas células do epitélio de revestimento (Epit.). Estas estão separadas do tecido conjuntivo (TC) subjacente pela lâmina basal (setas curtas). Observar uma longa fibra oxitalânica (setas), cortada longitudinalmente, que se insere na lâmina basal.

Figura 21 - Micrografia eletrônica de região superficial da prega vocal obtida de feto de 9 meses. È possível observar a lâmina basal (setas curtas) que separa as células do epitélio de revestimento (Epit.) do tecido conjuntivo subjacente (TC). Logo abaixo da lâmina basal, notam-se fibrilas de ancoragem constituídas por colágeno tipo VII (seta vermelha). Essas fibrilas promovem a interação biomecânica entre as fibrilas de colágeno do conjuntivo (seta roxa) e a lâmina basal, especificamente nas regiões em que aparecem os hemidesmossos na célula epitelial. Os hemidesmossos correspondem a estruturas especializadas de adesão entre a célula epitelial e a lâmina basal. Os hemidesmossos ancoram, do lado citoplasmático, os filamentos de citoqueratina da célula epitelial (asteriscos), enquanto que, do lado da matriz extracelular, interagem com as proteínas da lâmina basal, garantindo a continuidade molecular entre o tecido epitelial e o tecido conjuntivo. Uma vez que as fibrilas de colágeno VII (vistas nesta figura), juntamente com as fibras oxitalânicas (mostradas na Figura anterior) se inserem diretamente na lâmina basal, sugere-se que estas estruturas constituam a base morfofuncional sobre a qual se dá a transdução do sinal biomecânico célula-matriz e vice-versa. 

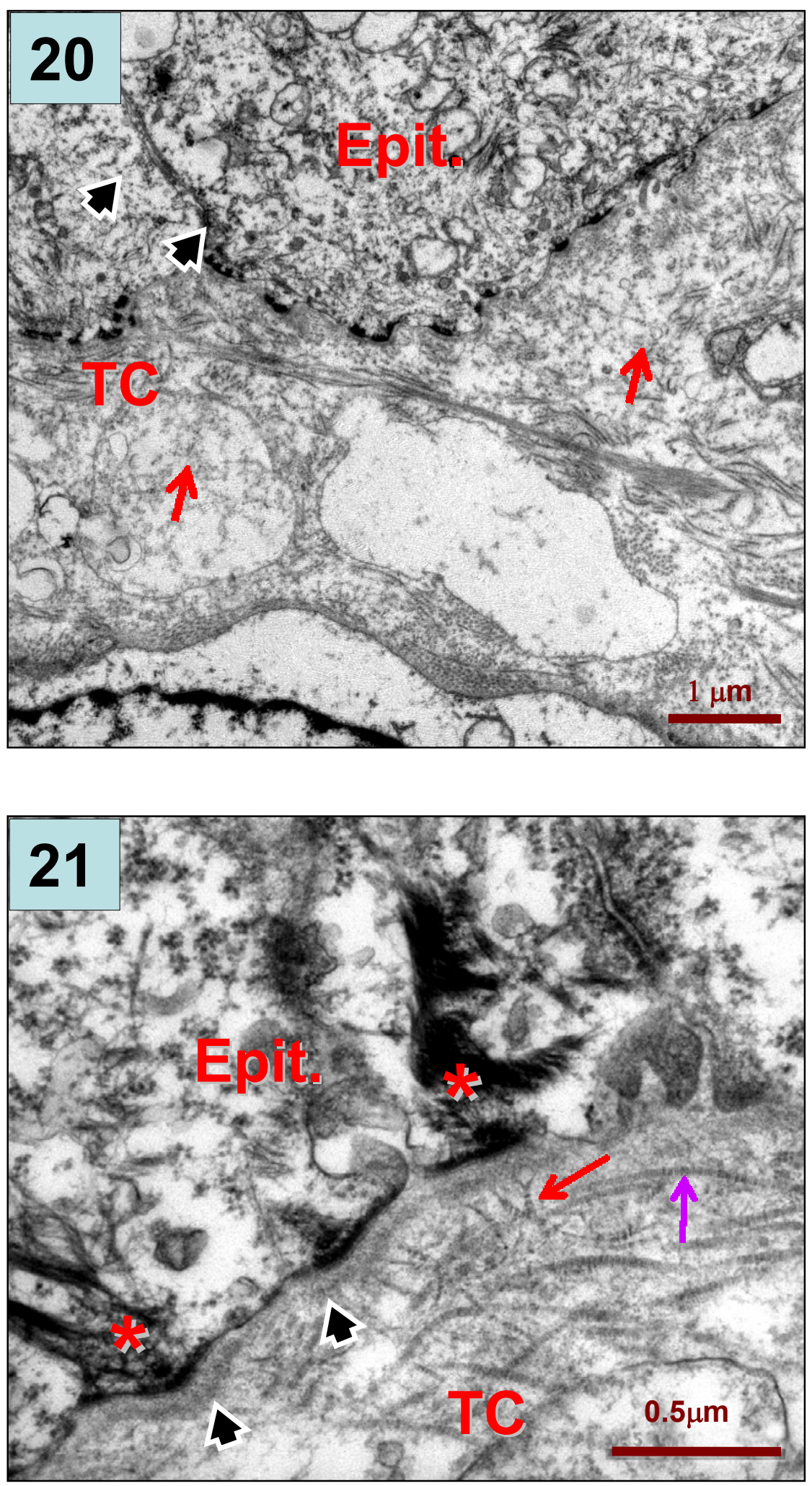
DISCUSSÃO 


\section{DISCUSSÃO}

O principal objetivo deste estudo foi obter informações a respeito das fibras do sistema elástico e colagênico (sob a luz dos conhecimentos atuais sobre a matriz extracelular), na lâmina própria de pregas vocais fetais no período perinatal.

Os resultados histoquímicos coincidem com as observações da microscopia eletrônica, mostrando populações de colágeno segregadas em diferentes compartimentos da lâmina própria. Assim, em sua região central, as fibras de colágeno se mostraram finas, fracamente birrefringentes de coloração esverdeada enquanto que as regiões superficiais e profundas apresentaram fibras grossas de colágeno que mostraram uma forte birrefringência de cor vermelho-amarelada, quando estudadas através do método da Picrossírius-polarização. Estas características sugerem fortemente que as fibras finas da região central são compostas principalmente por colágeno tipo III, enquanto o colágeno tipo I predomina nas regiões superficial e profunda, em concordância com as observações da literatura relativa ao estudo da prega vocal de adultos (HAMMOND et al., 2000; MELO et al., 2003).

Assim como o componente colagênico, as fibras do sistema elástico mostraram uma distribuição diferencial ao longo da lâmina própria. Em certo sentido, esta distribuição foi complementar àquela das fibras de colágeno: a região central, na qual fibras colagênicas eram escassas e finas, apresentou 
maior densidade de fibras do sistema elástico, em comparação às regiões superficial e profunda.

É difícil determinar as contribuições individuais dos componentes biológicos às propriedades biomecânicas. Como os tecidos conjuntivos apresentam predominantemente uma função mecânica, é importante se compreender como os constituintes químicos (colágeno, glicosaminoglicanos, fibras elásticas, minerais e água) fornecem ao tecido seus atributos mecânicos. No entanto, estas características variam entre os diferentes tipos de tecidos conjuntivos. Por exemplo, os tendões possuem um conteúdo maior de colágeno, fibrilas orientadas e menor quantidade de glicosaminoglicanos; outros tecidos especializados, tais como o ligamento nucal, são ricos em fibras elásticas e suas propriedades mecânicas são intensamente influenciadas por este componente (PARRY e CRAIG, 1988). Em termos de sua função mecânica, os tecidos conjuntivos devem apresentar combinações apropriadas de dois atributos básicos - a habilidade de resistir a grandes forças tênseis ou compressivas e a habilidade de recuperar sua forma e posição quando as forças cessam.

A acústica da fonação depende criticamente da biomecânica da vibração das pregas vocais, a qual é ditada pela interação das forças glóticas aerodinâmicas com as propriedades biomecânicas dos tecidos constituintes da prega vocal. A morfologia e a razão entre fibras elásticas e colágeno são consideradas como os principais fatores que determinam as propriedades físicas de cada camada da prega vocal. 
Neste sentido, as fibras elásticas longitudinais permitem uma rápida restauração da prega vocal para a posição original após seu estiramento longitudinal pela contração do músculo cricotireóideo. Assim sendo, as fibras elásticas desempenhariam um papel importante no mecanismo fonatório por restaurar rapidamente o tom natural da prega vocal.

É interessante observar que o presente estudo mostrou que as inserções da prega vocal nas extremidades anterior e posterior são diferentes entre si: enquanto que, na extremidade anterior, o tendão da comissura é rico em fibras colágenas e possui poucos elementos do sistema elástico, o processo vocal da extremidade posterior é uma região que, por sua natureza simultaneamente cartilaginosa e elástica, não apresenta fibras de colágeno (apenas fibrilas), sendo porém, rica em elementos elásticos. Certamente, estas características teciduais conferem propriedades biomecânicas diferentes às duas extremidades da prega vocal. Uma vez que a região posterior apresenta maior mobilidade promovendo a adução durante a fonação e a abdução para permitir a respiração é de se esperar que a estrutura apresente uma grande capacidade de retornar à sua posição original, de maneira rápida e eficiente.

As fibras colagênicas da lâmina própria sofrem estiramento a cada alongamento da prega vocal; a grande concentração de fibras elásticas na inserção posterior da prega vocal permitiria que esta região de intensa movimentação recuperasse rapidamente sua forma e posição, de modo a proporcionar a capacidade de adaptação necessária para que a regulação 
fina da contração da musculatura intrínseca da laringe seja traduzida de maneira extremamente rápida e eficaz em variações da qualidade vocal.

Os cortes horizontais corados com Picrossírius mostram que as fibras colagênicas apresentaram um padrão morfológico ondulado (crimp). Que seja do nosso conhecimento, esta observação é inédita na prega vocal, tanto para jovens como para adultos. De modo geral, as fibras colágenas de tendões e ligamentos apresentam crimps quando estão no estado relaxado; estes crimps desaparecem quando o tecido é estirado. Este fato demonstra a importância da existência dos crimps como um mecanismo de complacência através do qual a pequena variação do comprimento resultante do alongamento das regiões de colágeno "crimpado" previne o dano à estrutura como um todo durante o estágio inicial de uma contração muscular vigorosa (CALDINI et al., 1990; FEITOSA et al., 2002).

Segundo estudos biomecânicos, a presença de crimps das fibras colagênicas permite que ocorra seu estiramento mesmo com pequena força aplicada até o ponto em que os crimps se alongam. A partir deste ponto, a quantidade de força necessária para se conseguir um mesmo grau de estiramento torna-se comparativamente muito maior. Esta organização estrutural do colágeno é característica de ligamentos, tendões e de tecidos localizados em regiões submetidas a forças tênseis no organismo (SHAH et al., 1977), atuando de modo a manter a integridade estrutural, capacidade de alongamento e elasticidade dos tecidos.

Estes conceitos podem ser aplicados à prega vocal, uma vez que esta é submetida a forças constantes, de diferentes tipos, intensidades e 
velocidades conforme a atividade da musculatura intrínseca da laringe. Nossos achados demonstraram que, desde a idade fetal, a prega vocal humana apresenta uma estrutura preparada a submeter-se a forças de tensão. A presença de fibras elásticas dispostas paralelamente às fibras colagênicas com crimp levam à suposição que estas podem ser responsáveis pelo retorno do colágeno à sua configuração original após a retirada da força de alongamento, o que em última instância promoveria o retorno à configuração original da estrutura como um todo (CALDINI et al., 1990).

A melhor compreensão das contribuições biomecânicas das diferentes proteínas fibrilares presentes nas pregas vocais poderia facilitar a bioengenharia de construção de tecidos e materiais implantáveis para o tratamento de distúrbios vocais. Assim, é interessante que se conheça a sua organização ao nascimento, além das modificações sofridas ao longo da vida.

Nossos achados indicaram que, já em fetos de sete meses de idade, a lâmina própria da prega vocal humana apresenta uma complexa organização estrutural de suas fibras, muito semelhante àquela encontrada no adulto. Em contraste com a descrição clássica na literatura para pregas vocais de fetos e neonatos, encontramos uma organização estrutural na região central da lâmina própria que pode ser considerada semelhante àquela do ligamento vocal descrito em adultos.

Ainda que CAMPOS BAÑALES et al. (1995) tenham considerado que o ligamento vocal do adulto corresponde somente à faixa de tecido 
conjuntivo rico em fibras elásticas, a maioria dos autores considera que o ligamento vocal é constituído pelas camadas intermediária e profunda da lâmina própria (SATO e HIRANO, 1995; HIRANO et al., 1999; GRAY, 2000). Assim sendo, a descrição clássica consagrada preconiza que o ligamento vocal é composto por fibras colágenas densamente empacotadas e por fibras elásticas. Estas fibras estão alinhadas paralelamente e cursam na direção ântero-posterior entre a cartilagem tireóidea e o processo vocal da cartilagem aritenóidea.

O fato de que nossos resultados mostraram a presença de grande quantidade de fibras do sistema elástico na camada central da lâmina própria e grande quantidade de fibras colágenas na região profunda da lâmina própria permite afirmar que o ligamento vocal já está presente ao nascimento com a mesma organização estrutural do adulto.

Do ponto de vista clínico, mesmo nos dias atuais, os critérios de indicação e princípios da fonomicrocirurgia em idade infantil não estão bem estabelecidos. Alguns autores indicam que deve-se evitar ao máximo a manipulação cirúrgica das pregas vocais infantis pelo fato do ligamento vocal não estar completamente formado; outros sugerem que as lesões devem ser removidas para que o seu desenvolvimento histológico não seja comprometido. Além disso, atualmente os estudos indicam que não é só a manipulação do ligamento um fator crucial no sucesso de uma fonomicrocirugia. A presença dos proteoglicanos e os componentes da zona da membrana basal são fatores que devem ser levados em consideração, portanto futuros estudos complementares sobre a estrutura das pregas 
vocais infantis seriam necessários. Uma vez que nossos resultados mostraram a semelhança estrutural da prega vocal fetal com àquela do adulto, acreditamos que a indicação e a realização de fonomicrocirurgia em crianças devam seguir os mesmos fundamentos daqueles dos adultos.

O fato de que, somente este nosso trabalho tenha observado a distribuição diferencial dos elementos fibrosos na matriz extracelular da lâmina própria da prega vocal fetal pode ser atribuído a algumas razões: (1) é necessário estudar esta distribuição utilizando cortes horizontais de prega vocal, como aqueles deste trabalho, de forma a evidenciar, em um único preparado histológico, toda sua extensão ântero-posterior; (2) é necessário aplicar os diferentes métodos histoquímicos específicos para identificação das fibras da matriz extracelular em cortes histológicos seriados, para que a comparação dos resultados fornecidos por cada um dos métodos possa ser feita de maneira fidedigna.

Pela técnica de hematoxilina-eosina, tanto as fibras do sistema elástico quanto as finas fibras de colágeno não são identificados, como pudemos comprovar em nossos achados. Para identificação das fibras do sistema elástico foram utilizados, até o momento, técnicas de coloração que, embora consagradas para rotina histopatológica (como a hematoxilina férrica de Verhoeff, a orceína e a aldeído-fucsina) apresentam uma sensibilidade inferior ao método da resorcina-fucsina aplicado após oxidação do corte histológico. O método de Verhoeff demonstra seletivamente as fibras elásticas totalmente maduras, porém as fibras elaunínicas e oxitalânicas não são coradas. Por outro lado, o método de resorcina-fucsina de Weigert é 
mais sensível e assim, também cora fibras elaunínicas. Fibras oxitalânicas permanecem indetectáveis a menos que sejam antes oxidadas (MONTES, 1996).

Enquanto nas secções coradas pelo Picrossírius o colágeno adquire uniformemente a cor vermelho profundo (tornando possível definir precisamente sua distribuição), em secções coradas pela técnica rotineiramente usada do Tricrômio de Mallory, Masson e van Gieson, o colágeno é corado irregularmente, com coloração de algumas fibras e de outras não, o que dificulta a demonstração, de forma inequívoca, de sua presença (JUNQUEIRA e MONTES, 1983).

De modo a contornar estas dificuldades, utilizamos neste estudo métodos histoquímicos que permitiram a identificação dos três tipos de fibras do sistema elástico e do colágeno fibrilar. Além disso, realizamos observações ultra-estruturais em microscópio eletrônico de transmissão, que permitem o diagnóstico inequívoco dos diferentes tipos de fibras da matriz extracelular, além de evidenciar a interação dos diversos componentes entre si e com as células.

A grande quantidade de tempo despendida na observação das lâminas histológicas e na caracterização de diferentes compartimentos da lâmina própria nos levou a uma visão crítica das descrições morfológicas encontradas na literatura. Um dos pontos que merece atenção é a clássica divisão da lâmina própria em três camadas (superficial, intermediária e profunda). Embora a camada superficial de fibras colágenas seja bem definida já no feto de sete meses, não foi possível a distinção do limite entre 
a camada profunda da lâmina própria e o epimísio do músculo vocal. Neste ponto nossas observações concordaram com HAMMOND et al. (2000), estudando a prega vocal adulta. Com base nestas observações, pode-se sugerir que, talvez, a camada profunda da lâmina própria corresponda simplesmente ao epimísio do músculo vocal. Esta proposta ganha consistência quando se observa que as fibras da matriz extracelular desta camada profunda penetram no músculo vocal, separando os fascículos musculares, como é classicamente descrito para as bainhas conjuntivas (epimísio, perimísio e endomísio) que revestem qualquer tecido muscular. Estas ponderações nos levam a acreditar que as análises quantitativas da distribuição dos elementos da matriz extracelular nas diferentes camadas da lâmina própria devam ser interpretadas com cautela.

O conceito corrente de que os estímulos externos, como a fonação, são essenciais para a determinação da estrutura em camadas da lâmina própria, faz com que nossos resultados sejam surpreendentes ao evidenciar a presença de uma distribuição complexa e organizada dos componentes do tecido conjuntivo na lâmina própria de pregas vocais de fetos no período perinatal. A idéia de que a contribuição genética poderia desempenhar um papel importante na organização destas camadas, independentemente do estímulo mecânico, poderia explicar melhor a presença das estruturas observadas já ao nascimento, uma vez que o mecanismo genético pode agir antes de qualquer estímulo mecânico externo, como a fonação.

O padrão de distribuição diferencial das fibras dos sistemas colagênico e elástico sugere fortemente que o colágeno em co-evolução 
com o sistema elástico (e provavelmente com outras macromoléculas da matriz extracelular) têm contribuído amplamente para acomodar a diversidade funcional (MONTES, 1996). De fato, na prega vocal ainda no período perinatal, foi possível detectar os três tipos de fibras do sistema elástico. A diferença na qualidade da elasticidade apresentada por estas fibras, desde as oxitalânicas (inelásticas) até as fibras elásticas com muita elastina, confere uma característica multi-facetada ao sistema.

A matriz extracelular da prega vocal fetal apresenta exuberantes elementos ancoragem: as fibrilas de colágeno VII estavam presentes em grande quantidade na região da lâmina basal e as microfibrilas das fibras oxitalânicas apareceram ancoradas na lâmina basal do epitélio, na superfície celular, nas fibrilas de colágeno e em outras estruturas da matriz.

A interação dos elementos da matriz entre si e com as células faz com que a estrutura se comporte funcionalmente como um todo e corresponde à base morfológica do fenômeno de transdução dos estímulos mecânicos da matriz para as células. A comunicação dinâmica entre as células e os componentes da matriz influencia processos celulares como migração, proliferação e sobrevivência, regula os processos de diferenciação e reparo tecidual, além de modular a resposta celular a fatores de crescimento e citocinas (FUJA et al., 2006).

O conhecimento sobre a interação entre as células da prega vocal e a matriz extracelular circundante poderá contribuir muito na compreensão do desenvolvimento normal da laringe, de suas patologias e no desenvolvimento de futuras estratégias terapêuticas. 


\section{CONCLUSÕES}




\section{CONCLUSÕES}

Em contraste com a descrição clássica na literatura para pregas vocais de fetos e neonatos, nossos resultados histoquímicos coincidentes com as observações da microscopia eletrônica evidenciaram a presença de um padrão de distribuição diferencial das fibras da matriz extracelular na prega vocal humana fetal. Este padrão mostrou-se equivalente à descrição da lâmina própria da prega vocal de adultos. Adicionalmente, a observação da presença de grande quantidade de fibras do sistema elástico na camada central da lâmina própria e grande quantidade de fibras colágenas na região profunda da lâmina própria permite afirmar que o ligamento vocal já está presente ao nascimento com a mesma organização estrutural do adulto. 


\section{REFERÊNCIAS}




\section{REFERÊNCIAS}

Alberts $B$ et al. The extracelular matrix of animals. Molecular biology of the cell. $4^{\circ}$ ed. Ed New York \& London, Garland, 2002, p. 971-84.

Böck P. Histochemical demonstration of disulphidic-groups in the lamina propria of human seminiferous tubules. Anat Embryol. 1978; 153: 157-66.

Böck P, Stockinger L. Light and electron microscopic identification of elastic, elaunin and oxytalan fibers in human tracheal and bronchial mucosa. Anat Embryol. 1984; 170: 145-53.

Bradamante Z, Svajger A. Pre-elastic (oxytalan) fibres in the developing elastic cartilage of the external ear of the rat. J. Anat. 1977; 123: 735-43.

Buhler RB, Sennes LU. Estudo imunohistoquímico do proteoglicano versican e do sistema de fibras colágenas na lâmina própria de prega vocal de laringes fetais. Rev Bras Otorrinolaringol. 2007; 73 (Suplemento): A9.6 (Apresentado no V Congresso Triológico de Otorrinolaringologia; 6 a junho de 2007; Brasília, Brasil. Resumos)

Caldini EG, Caldini N, De-Pasquale V, Strocchi R, Guizzard S, Ruggeri S, Montes GS. Distribution of elastic system fibres in the rat tail tendon and its associated sheaths. Acta Anat. 1990; 139: 341-8. 
Campos Bañales ME, Pérez Piñero B, Rivero J, Ruíz Casal E, López Aguado D. Histological structure of the vocal fold in the human larynx. Acta Otolaryngol. 1995; 115: 701-4.

Chan RW, Fu M, Young L, Tirunagari N. Relative contributions of collagen and elastin to elasticity of the vocal fold under tension. Ann Biomed Eng. 2007; 35 (8): 1471-83.

Cotta-Pereira G, Rodrigo FG, Bittencourt-Sampaio S. Oxytalan, elaunin and elastic fibers in the human skin. J. Invest. Dermatol. 1976; 66: 143-8.

Cotta-Pereira G, Del-Caro LM, Montes GS. Distribution of elastic system fibers in hyaline and fibrous cartilages of the rat. Acta Anat. 1984: 119: 805.

Dikkers FG, Hulstaert CE, Oosterbaan JA, Cervera-Paz FJ. Ultrastructural changes of the basement membrane zone in benign lesions of the vocal folds. Acta Otolaryngol. 1993; 113: 98-101.

Ding H, Gray SD. Senescent expression of genes coding collagens, collagen-degrading metalloproteinases, and tissue inhibitors of metalloproteinases in rat vocal folds: comparison with skin and lungs. J Gerontol A Biol Sci Med Sci. 2001; 56 (4): 145-52.

Feitosa VL, Vidal BC, Pimentel ER. Optical anisotropy of a pig tendon under compression. J Anat. 2002; 200: 105-11. 
Ferreira JMC, Caldini EG, Montes GS. Distribution of elastic system fibers in the peripheral nerves of mammals. Acta Anat. 1987; 130: 168-73.

Fuja TJ, Ostrem EM, Probst-Fuja MN, Titze IR. Matrix Biol. 2006; 25: 240-51.

Fullmer HM, Lillie RD. The oxytalan fiber: a previously undescribed connective tissue fiber. J Histochem Cytochem. 1958; 6: 425-30.

Fullmer HM. A comparative histochemical study of elastic, pre-elastic and oxytalan connective tissue fibers. J Histochem Cytochem. 1960; 8: 290-5.

Gawlik Z. Morphological and morphochemical properties of the elastic system in the motor organ of man. Folia Histochem Cytochem. 1965; 3: 233-51.

Gerli R, Ibba L, Fruschelli C. A fibrillar elastic apparatus around human lymph capillaries. Anat Embryol 1990; 181: 281-6.

Gibson MA, Clearly EG. The immunohistochemical localization of microfibrilassociated glycoprotein (MAGP) in elastic and non elastic tissues. Immunol Cell Biol. 1987; 6: 345-56.

Gray SD, Pignatari SSN, Harding P. Morphologic ultrastructure of anchoring fibers in normal vocal fold basement membrane zone. J Voice. 1994; 8 (1): 48-52.

Gray, S.D. Cellular physiology of the vocal folds. Otolaryngol Clin North Am. 2000; 33 (4): 679-97. 
Gray SD, Chan KJ, Turner B. Dissection plane of the human vocal fold lamina propria and elastin fibre concentration. Acta Otolaryngol. 2000; 120 : 87-91.

Gray SD, Titze IR, Alipour F, Hammon TH. Biomechanical and histologic observations of vocal fold fibrous proteins. Ann Otol Rhinol Laryngol. 2000; 109: $77-85$.

Hammond TH, Zhou R, Hammond EH, Pawlak A, Gray SD. The intermediate layer: a morphologic study of the elastin and hyaluronic acid constituents of normal human vocal folds. J Voice. 1997; 11 (1): 59-66.

Hammond TH, Gray SD, Butler J, Zhou R, Hammond E. Age- and genderrelated elastin distribution changes in human vocal folds. Otolaryngol Head Neck Surg. 1998; 119: 314-22.

Hammond TH. Age- and gender-related collagen distribution in human vocal folds. Ann Otol Rhinol Laryngol. 2000; 109: 913-20.

Hartnick CJ, Rehbar R, Prasad V. Development and maturation of the pediatric human vocal fold lamina propria. Laryngoscope. 2005; 115: 4-15.

Hirano M. Morphological structure of the vocal cord as a vibrator and its variations. Folia Phoniatr Logop. 1974; 26: 89-94.

Hirano M, Kurita S, Sakaguchi S. Ageing of the vibratory tissue of human vocal folds. Acta Otolaryngol. 1989; 107: 428-33. 
Hirano M, Sato K, Nakashima T. Fibroblasts in human vocal fold mucosa. Acta Otolaryngol. 1999; 119: 271-76.

Imamura R, Tsuji DH, Sennes LU. Fisiologia da laringe. In: Campos $\mathrm{CAH}$, Costa HOO. Tratado de otorrinolaringologia. São Paulo : Editora Roca Ltda; 2002. V. 1, p. 751-67.

Ishii K, Zhai WG, Akita M, Hirose $\mathrm{H}$. Ultrastrucutre of the lamina propria of the human vocal fold. Acta Otolaryngol. 1996; 116: 778-82.

Ishii K, Yamashita K, Akita M, Hirose H. Age-related development of the arrangement of connective tissue fibers in the lamina propria of the human vocal fold. Ann Otol Rhinol Laryngol. 2000; 109: 1055-64.

Isshiki N. Fisiologia da produção da fala. In: Isshiki N, Tsuji DH, Sennes LU. Tireoplastias. São Paulo: Bios Comunicação e Editora Ltda; 1999. p. 19-30. Junqueira LC, Bignolas G, Brentani RR. Picrosirius staining plus polarization microscopy, a specific method for collagen detection in tissue sections. Histochem J. 1979; 11 (4): 447-55.

Junqueira LCU, Montes GS, Martins JEC, Joazeiro PP. Dermal collagen distribution. A histochemical and ultrastructural study. Histochemistry. 1983; 79: 397-402.

Konomi H, Hayashi T, Nakayasu K, Arima M. Localization of type V collagen and type IV collagen in human cornea, lung, and skin. 
Immunohistochemical evidence by anti-collagen antibodies characterized by immunoelectroblotting. A J Pathol.1984; 116 (3): 417-26.

Lefevre M, Rucker RB. Aorta elastin turnover in normal and hypercholesterolemic japanese quail. Biochim Biophys Acta. 1980; 630: $519-29$.

Lemos M, Pozo RMK, Montes GS, Saldiva PHN. Organization of collagen and elastic fibers studied in stretch preparations of whole mounts of human visceral pleura. Ann Anat. 1997; 179: 447-52.

Lopez-De Leon A, Rojkind M. A simple micromethod for collagen and total protein determination in formalin-fixed paraffin-embedded sections. J Histochem Cytochem. 1985; 33 (8): 737-43.

Mecham RP, Heuser JE. The elastic fiber. In: HAY ed. Cell Biology of Extracellular Matrix. New York, Plenum Press. 1991. p.79-109.

Melo ECM, Lemos M, Ximenes Filho JA, Sennes LU, Saldiva PHN, Tsuji DH. Distribution of collagen in the lamina propria of the human vocal fold. Laryngoscope. 2003; 113 (12): 2187-91.

Milutinovic Z, Polic D, Milenkovic S, Sretenovic V. Spatial arrangement of the structural elements of vocal fold layers: an adjustment to the vibration process. J Voice. 1998; 12 (1): 17-20. 
Montes GS, Krisztan RM, Junqueira LC. Preservation of elastic system fibers and of collagen molecular arrangement and stainability in an Egyptian mummy. Histochemistry. 1985; 83 (2): 117-9.

Montes GS. Structural biology of the fibres of the collagenous and elastic systems. Cell Biol Int. 1996; 20 (1): 15-27.

Parry DAD, Craig AS. Collagen fibrils during development and maturation and their contribution to the mechanical attributes of connective tissue. In: Nimni ME (ed.) Collagen. Vol II. Boca-Raton, CRC Press, 1988. p.1-23.

Partridge SM. Elastin. Adv. Prot. Chem. 1962; 17: 227-302.

Paulsen F, Kimpel M, Lockemann U, Tillmann B. Effects of ageing on the insertion zones of the human vocal fold. J Anat. 2000; 196: 41-54.

Ramos HVL, Neves LR, Barbosa LHF, DE Biase NG, Oshima CTS, Simões MJ, Pontes PAL. Imunohistoquímica como método de estudo das fibras elásticas em prega vocal humana. Rev Bras Otorrinolaringol. 2005; 71 (4): $486-91$.

Robinson TH, Cohen-Gould L, Factor SM. Skeletal framework of mammalian heart muscle. Laboratory Investigation. 1983; 49 (4): 482-98.

Rodrigo FG, Cotta-Pereira G, David-Ferreira JF. The fine strutural of the elastic tendons in the human arrector pili muscle. $\mathrm{Br} \mathrm{J}$ Dermatol. 1975; 93: $631-7$ 
Rosenbloom J, Abrams WR, Mecham R. The elastic fiber. Faseb J. 1993; 7: 1208-18.

Ross R, Bornstein P. The elastic fiber. I. The separation and partial characterization of macromolecular components. J Cell Biol. 1969; 40: 36681.

Ross R, Fialkow PJ, Altman K. The morphogenesis of elastic fibers. Adv. Exp. Med. Biol. 1977; 79: 7-17.

Sage H, Gray WR. Studies on the evolution of elastin. I. Philogenetic distribution. Comp. Biochem. Physiol. 1979; 64: 313-27.

Sato K, Hirano, M. Histologic investigation of the macula flava of the human vocal fold. Ann Otol Rhinol Laryngol. 1995; 104: 138-43.

Sato K, Hirano, M. Histologic investigation of the macula flava of the human newborn vocal fold. Ann Otol Rhinol Laryngol. 1995; 104: 556-62.

Sato K, Hirano M. Age-related changes of the macula flava of the human vocal fold. Ann Otol Rhinol Laryngol. 1995; 104: 839-44.

Sato K, Hirano M. Age-related changes of elastic fibers in the superficial layer of the lamina propria of vocal folds. Ann Otol Rhinol Laryngol. 1997; 106: 44-48.

Sato K. Reticular fibers in the vocal fold mucosa. Ann Otol Rhinol Laryngol. 1998; 107: 1023-8. 
Sato K, Hirano M, Nakashima T. Ultrastructure of the vocal process of the arytenoid cartilage. Ann Otol Rhinol Laryngol. 2000; 109: 650-3.

Sato K, Hirano M, Nakashima T. Stellate cells in the human vocal fold. Ann Otol Rhinol Laryngol. 2001; 110: 319-25.

Sato K, Hirano M, Nakashima T. Fine structure of the human newborn and infant vocal fold mucosae. Ann Otol Rhinol Laryngol. 2001; 110: 417-24.

Sato K, Hirano M, Nakashima T. Age-related changes of collagenous fibers in the human vocal fold mucosa. Ann Otol Rhinol Laryngol. 2002; 111: 1520.

Sato K, Hirano M, Nakashima T. 3D structure of the macula flava in the human vocal fold. Acta Otolaryngol. 2003; 123: 269-73.

Shah JS, Jayson MIV, Hampson WGJ. Low tension studies of collagen fibres from ligaments of the human spine. Ann Rheum Dis. 1977; 36: 139-45.

Shapiro SD, Endicott SK, Province MA, Pierce JA, Campbell EJ. Marked longevity of human lung parenchymal elastic fibers deduced from prevalence of D-aspartate and nuclear weapons-related radiocarbon. J. Clin. Invest. 1991; 87: 1828-34.

Souza AD, Montes GS, Vilela BTX, Cruz AC, Cotta-Pereira G. Elastic-related fibers in the annular ligament of the stapes-oval window articulation. An electron microscopic and histochemical study in the rat and the rabbit. Rev Laryngol. 1991; 112: 7-10. 
Streeten BW, Licari PA. The zonules and the elastic microfibrillar system in ciliary body. Invest Ophtalmol. 1983; 24: 667-81.

Subotic R, Vecerina S, Krajina Z, Hirano M, Kurita S. Histological structure of vocal fold lamina propria in foetal larynx. Acta Otolaryngol. 1984; 97: 403-6.

Tateya T, Tateya I, Bless DM. Collagen subtypes in human vocal folds. Ann Otol Rhinol Laryngol. 2006; 115 (6): 469-76.

Wetzels RH, Robben HC, Leigh IM, Schaafsma HE, Vooijs GP, Ramaekers FC. Distribution patterns of type VII collagen in normal and malignant human tissues. Am J Pathol. 1991; 139 (2): 451-9. 


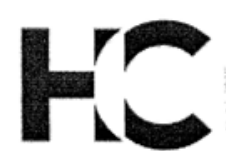

DIRETORIA CLÍNICA

\section{Comissão de Ética para Análise de Projetos de Pesquisa}

\section{APROVAÇÃO}

A Comissão de Ética para Análise de Projetos de Pesquisa - CAPPesq da Diretoria Clínica do Hospital das Clínicas e da Faculdade de Medicina da Universidade de São Paulo, em sessão de 25.03.04, APROVOU o Protocolo de Pesquisa $n^{\circ}$ 132/04, intitulado: "Estudo histoquímico e ultra-estrutural dos padrões de distribuição das fibras da matriz extracelular na prega vocal humana ao longo do desenvolvimento" apresentado pelo Departamento de OFTALMOLOGIA E OTORRINOLARINGOLOGIA.

Pesquisador(a) Responsável: Dr. Domingos Hiroshi Tsuji

Pesquisador(a) Executante: Dra. Luciana Miwa Nita

CAPPesq, 25 de Março de 2004.

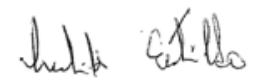

PROF. DR. EUCLIDES AYRES DE CASTILHO

Presidente da Comissão de Ética para Análise de Projetos de Pesquisa Saúde $n^{\circ} 196$, de 10.10.1996, inciso IX.2, letra " $c$ ") 